\title{
Postcranial adaptations for leaping in primates
}

\author{
Jacqueline Runestad Connour ${ }^{1}$, Kenneth Glander ${ }^{2}$ and François Vincent ${ }^{3}$ \\ ${ }^{1}$ Department of Biological Sciences, Western Illinois University, One University Circle, Macomb, IL 61455, U.S.A. \\ ${ }^{2}$ Duke University Primate Center, Durham, NC 27705, U.S.A. \\ ${ }^{3}$ Psychophysiologie et Éthologie, Université de Paris X, Nanterre, 78650 Saulx-Marchais, France \\ (Accepted 7 July 1999)
}

\begin{abstract}
Leaping primates are specialized for hindlimb-propelled locomotion within arboreal habitats. As a group, they include members of Galagonidae, Lemuriformes and Tarsiidae. Postcranial characters analysed here include humeral and femoral diaphyseal rigidity, articular surface areas and lengths. Data for leaper taxa are compared with corresponding data for less specialized small primates. The more generalized comparative primates include both closely related prosimians and distantly related platyrrhines (New World monkeys). In addition, the leapers are subdivided for further analysis according to body size and taxonomic association. Questions addressed concern the identification of functionally and/ or phylogenetically linked traits in leaper postcrania. Results indicate that leapers as a group have relatively higher femoral diaphyseal rigidity and longer femora than do more generalized primates. These traits are also present in Pithecia pithecia, a platyrrhine leaper included for comparison. These enhanced properties probably function in resisting large hindlimb forces incurred during leaping, and in producing longer, more efficient leaps. Most of the large-bodied lemuriform leapers are further distinguished in having relatively bigger femoral heads and reduced humeral rigidity. The small-bodied leapers, galagonids and tarsiids, do not differ in either femoral head surface area or in any of the humeral properties from more generalized primates. Pithecia has a large femoral head like lemuriforms, but it is not reduced in humeral rigidity. Aspects of hip joint structure and mobility may be related to femoral head size in lemuriforms and Pithecia. Explanations regarding reduced lemuriform humeral rigidity are also explored. Differences between lemuriform primates are also present, most notably in aspects of the distal humerus. Indrids are characterized by relatively reduced trochleae, while many lemurids have relatively small capitula. These features are interpreted with regard to frequencies of suspensory behaviour and quadrupedalism.
\end{abstract}

Key words: leaping behaviour, skeleton, primates, body size

\section{INTRODUCTION}

Leaping is a common locomotory specialization in small primates. It is the most frequent means of locomotion for members of at least three different primate groups: Galagonidae, Lemuriformes and Tarsiidae (Petter, 1962; Crompton, 1984; Crompton \& Andau, 1986; Dagosto, 1995).

This study compares the biomechanical aspects of the limb bones of leapers to those of less specialized small primates. Humeral and femoral diaphyseal crosssectional properties, articular dimensions and lengths are compared to identify features that leapers have in common which are not seen in primates with more generalized locomotory behaviour. In addition, differ- ences among leaper taxa are examined in relation to body size and phylogeny.

Cross-sectional and articular morphological data of limb bones are considered together for several taxa of both closely and distantly related small primates. This is important because articular dimensions and bone lengths are probably primarily determined by genetic factors, so that major changes occur over evolutionary time, while diaphyseal cross-sectional data largely reflect individual lifetime usage patterns (Currey, 1968). Thus, it is possible for an animal to have articular morphology that does not correspond to theoretical expectations based on its locomotory behaviour, but that matches the expectations for related animals with different behaviour. Additionally, if the same 
behaviours are displayed by distantly related animals such as prosimians and platyrrhines, such behaviours may be produced by either similar or different anatomical designs. Thus, the results presented in this study that compare both articular and cross-sectional data are of particular interest. Evidence for anatomical convergence and divergence is examined for behaviour, body size and phylogenetic history.

The results of this study have potential for identifying leaping adaptations in fossil primates. Many of the earliest primates may have been leaping specialists; diverse Eocene prosimians from China, North America and western Europe show morphological similarities to extant primate leapers (Dagosto, 1985, 1988; Rose \& Walker, 1985; Thalmann, Haubold \& Martin, 1989; Beard et al., 1994; Dagosto \& Schmid, 1996). Remains of Apidium phiomense, an Oligocene anthropoid from Egypt, also show evidence of strong leaping ability (Fleagle \& Simons, 1983). Finally, Miocene prosimian material from East Africa closely resembles the postcrania of living galagonids (A. Walker, 1970).

We define leaping as hindlimb-propelled jumping. It is further characterized by the ability to hop bipedally, frequent clinging to vertical supports and frequent maintenance of vertical body posture during leaps (Napier \& Walker, 1967; Oxnard, Crompton \& Lieberman, 1990). Leapers included in this study are Galagonidae (bushbabies), Hapalemur (bamboo lemurs), Indridae (sifakas, indris and woolly lemurs), Lepilemur (sportive lemurs), and Tarsius (tarsiers) (Petter \& Peyrieras, 1975; Pollock, 1975; CharlesDominique \& Bearder, 1979; Crompton \& Andau, 1986; Dagosto, 1995; Warren \& Crompton, 1997).

Leapers contrast with more generalized small primates such as Cheirogaleidae (dwarf lemurs), Daubentonia madagascariensis (the aye-aye) and many Platyrrhini (New World monkeys). These primates frequently use all four limbs in varied ways for locomotion. Quadrupedal running, bounding and walking are common locomotory behaviours, and these animals are also adept at leaping and suspension (Petter \& Peyrieras, 1970a; Petter, Schilling, \& Pariente, 1971; Fleagle \& Mittermeier, 1980; Oxnard, 1981; Garber, 1991; S. E. Walker, 1994). These less specialized primates are referred to in this study as generalized quadrupeds, or generalists. Part of the generalist data are also presented in Runestad (1997), where they are used for comparison with climbing Loridae (pottos and lorises).

In addition to the two primary groups, leapers and generalists, other small primates that contribute to this study include several species of Lemuridae (lemurs) that form an intermediate group between generalists and leapers. Observations of locomotory behaviour for many lemurids usually indicate leaping frequencies between those reported for leaping and generalist taxa (Gebo, 1987; Pereira, Seeligson \& Macedonia, 1988; Tilden, 1990; Dagosto, 1994, 1995).

A sample of large New World monkeys, consisting of the Atelinae (howler, woolly and spider monkeys), serves to extend the body-size range of primates that are not specialized for leaping. The atelines are not part of the generalist sample because they are more suspensory and less likely to leap than are the generalists (Fleagle \& Mittermeier, 1980; Bergeson, 1996).

There are also individual taxa that differ from their closest relatives in locomotory behaviour. Examples in this study are Otolemur species (thick-tailed bushbabies) which are the largest galagos, and Pithecia pithecia (the white-faced saki), a platyrrhine. Unlike most other galagos, Otolemur species are predominantly quadrupedal runners and walkers (Bearder \& Doyle, 1974; Charles-Dominique \& Bearder, 1979; Crompton, 1984). In contrast, Pithecia differs from most other platyrrhines in that it leaps much more frequently than it travels quadrupedally, and it can hop on its hindlimbs (Fleagle \& Mittermeier, 1980; S. E. Walker, 1994, 1996). Comparisons of these animals with related animals that are behaviourally different, and unrelated animals that are behaviourally similar, help address questions about the relative effects of phylogeny versus function on limb bone morphology.

\section{MATERIALS}

Table 1 lists species, locomotor preferences, numbers of individuals per species, collections of origin, and body masses. The total sample is divided into leapers (small, mid-sized and large), generalists (platyrrhine and prosimian), lemurids and atelines.

All specimens are adult and almost all were shot in the wild. Exceptions are several specimens of Daubentonia which died very early in captivity and 2 Cebuella specimens which were reared in semi-natural captivity (Christen, 1974). No primates were killed specifically for this project.

Almost all literature-based body masses used are from non-captive animals, but captive animal body masses are used for some lemurids. These masses were amended to reflect captive/wild-shot differences observed for related species. Wild-shot masses given in Glander et al. (1992) for Eulemur fulvus and Eulemur rubriventer are c. $10 \%$ lighter than those given for the same species from Duke University Primate Centre records (Kappeler, 1991), and so the captive masses given by Kappeler (1991) for Lemur catta, Eulemur coronatus, and Eulemur macaco are reduced by $10 \%$ to produce the estimates given in Table 1. Similar differences between wild and captive primate body masses were also found by Vincent (1969) in his study of Galagoides demidoff.

Both major locomotory categories, leapers and generalists, are split into subgroups. Large leapers (the indrids), and small leapers, (galagonids and tarsiers), are compared with each other. The mid-sized leapers, Lepilemur and Hapalemur, are not labelled as either large or small leapers because on bivariate plots they do not consistently group with either subgroup (see Figs 3, $7-9,10 \& 11)$. The generalists are split into platyrrhine 
Table 1. Sample information

\begin{tabular}{|c|c|c|c|c|c|}
\hline Taxon $^{\mathrm{a}}$ & Locomotory preference & $n^{\mathrm{b}}$ & Collection $^{\mathrm{c}}$ & $\begin{array}{l}\text { Body mass }{ }^{d} \\
(g)\end{array}$ & Source of body mass ${ }^{\mathrm{e}}$ \\
\hline \multicolumn{6}{|l|}{ Leapers } \\
\hline Galago elegantulus & Small leaper & 10 & London, Zurich & 300 & Charles-Dominique, 1977 \\
\hline Galago matschiei & Small leaper & 4 & Nanterre & 205 & Assoc. \\
\hline Galago moholi & Small leaper & 5 & AMNH, London, MCZ & 205 & S. K. Bearder, pers. comm. \\
\hline Galago senegalensis & Small leaper & 11 & AMNH, London, MCZ & 202 & Harcourt, 1984 \\
\hline Galagoides alleni & Small leaper & 8 & Nanterre & 265 & Assoc. \\
\hline Galagoides demidoff ${ }^{\mathrm{f}}$ & Small leaper & 11 & $\begin{array}{l}\text { AMNH, London, MCZ, } \\
\text { USNM }\end{array}$ & 64 & $\begin{array}{l}1 \text { assoc.; } 10 \text { Charles-Dominique } \\
\text { \& Martin, } 1972\end{array}$ \\
\hline Tarsius bancanus & Small leaper & 3 & MCZ, USNM, Zurich & 120 & 1 assoc.; 2 Fogden, 1974 \\
\hline Tarsius syrichta & Small leaper & 4 & USNM, Zurich & 113 & Bearder, 1987 \\
\hline Hapalemur griseus & Mid-sized leaper & 11 & AMNH, MCZ, USNM & 770 & Glander et al. 1992 \\
\hline Lepilemur mustenlinus & Mid-sized leaper & 11 & AMNH, USNM & 790 & U. Thalmann, pers. comm. \\
\hline Avahi laniger & Large leaper & 13 & $\begin{array}{l}\text { AMNH, Leiden, MCZ, } \\
\text { USNM, Zurich }\end{array}$ & 1175 & Glander et al., 1992 \\
\hline Indri indri & Large leaper & 6 & $\begin{array}{l}\text { AMNH, London, Leiden, } \\
\text { MCZ, MNHN }\end{array}$ & 7500 & Demes \& Jungers, 1993 \\
\hline Propithecus diadema & Large leaper & 7 & $\begin{array}{l}\text { AMNH, Leiden, MCZ, } \\
\text { MNHN }\end{array}$ & 5794 & Glander et al., 1992 \\
\hline Propithecus verreauxi & Large leaper & 9 & $\begin{array}{l}\text { AMNH, Leiden, MCZ, } \\
\text { MNHN }\end{array}$ & 2965 & Richard, 1992 \\
\hline Pithecia pithecia & Platyrrhine leaper & 4 & Leiden, USNM & 1700 & Ford \& Davis, 1992 \\
\hline \multicolumn{6}{|c|}{ Intermediate leaping frequency } \\
\hline Lemur catta & Intermediate leaper & 3 & AMNH, MNHN & 2423 & amended Kappeler, 1991 \\
\hline Eulemur coronatus & Intermediate leaper & 3 & MNHN & 1530 & amended Kappeler, 1991 \\
\hline Eulemur macaco & Intermediate leaper & 3 & MNHN & 2201 & amended Kappeler, 1991 \\
\hline Eulemur fulvus & Intermediate leaper & 9 & AMNH & 2185 & Glander et al., 1992 \\
\hline Eulemur rubriventer & Intermediate leaper & 4 & MCZ, MNHN & 2014 & Glander et al., 1992 \\
\hline Varecia variegata & Intermediate leaper & 9 & $\begin{array}{l}\text { AMNH, Leiden, MCZ, } \\
\text { MNHN }\end{array}$ & 3000 & Ave. 2 pelts USNM \\
\hline \multicolumn{6}{|c|}{ Generalists (most are also listed in Runestad, 1997) } \\
\hline Aotus azarae & Generalist & 9 & AMNH & 1290 & 4 assoc., 5 ave. of other assoc. \\
\hline Aotus trivirgatus & Generalist & 2 & AMNH, USNM & 869 & Assoc. \\
\hline Callithrix jacchus & Generalist & 4 & AMNH, USNM & 307 & Assoc. \\
\hline Cebuella pygmaea & Generalist & 3 & USNM, Zurich & 123 & Ford \& Davis, 1992 \\
\hline $\begin{array}{l}\text { Cebus albifrons } \\
\quad \text { (females) }\end{array}$ & Generalist & 9 & AMNH & 2156 & Assoc. \\
\hline Cebus albifrons (males) & Generalist & 8 & AMNH & 3325 & Assoc. \\
\hline Cheirogaleus major & Generalist & 7 & $\begin{array}{l}\text { AMNH, London, MCZ, } \\
\text { USNM }\end{array}$ & 436 & Stephan \& Bauchot, 1965 \\
\hline Cheirogaleus medius & Generalist & 4 & Leiden & 180 & $\begin{array}{l}\text { Hladik, Charles-Dominique \& } \\
\quad \text { Petter, } 1980\end{array}$ \\
\hline Chiropotes satanas & Generalist & 4 & $\begin{array}{l}\text { AMNH, Leiden, MCZ, } \\
\text { USNM }\end{array}$ & 3125 & Ave. of 8 Leiden pelts \\
\hline $\begin{array}{l}\text { Daubentonia } \\
\quad \text { madagascariensis }\end{array}$ & Generalist & 4 & AMNH, Leiden, USNM & 2700 & E. Sterling, pers. comm. \\
\hline Microcebus murinus & Generalist & 6 & AMNH & 65 & $\begin{array}{l}\text { Charles-Dominique \& Martin, } \\
1972\end{array}$ \\
\hline Microcebus rufus & Generalist & 4 & USNM & 46 & $\begin{array}{l}\text { Charles-Dominique \& Martin, } \\
1972\end{array}$ \\
\hline Mirza coquereli & Generalist & 1 & Leiden & 308 & Hladik et al., 1980 \\
\hline Phaner furcifer & Generalist & 2 & Leiden, MNHN & 300 & $\begin{array}{l}\text { Charles-Dominique \& Petter, } \\
1980\end{array}$ \\
\hline Saguinus midas & Generalist & 8 & AMNH, London, Leiden & 537 & $\begin{array}{l}1 \text { assoc., } 7 \text { ave. of } 10 \text { Leiden } \\
\text { pelts }\end{array}$ \\
\hline Saguinus mystax & Generalist & 6 & AMNH & 542 & Ford \& Davis, 1992 \\
\hline $\begin{array}{l}\text { Saimiri sciureus } \\
\quad \text { (females) }\end{array}$ & Generalist & 10 & AMNH & 739 & Assoc. \\
\hline Saimiri sciureus (males) & Generalist & 9 & AMNH & 889 & Assoc. \\
\hline $\begin{array}{l}\text { Otolemur } \\
\quad \text { crassicaudatus }\end{array}$ & Galagonid generalist & 7 & $\begin{array}{l}\text { AMNH, London, MCZ, } \\
\text { USNM }\end{array}$ & 1200 & Masters, 1985 \\
\hline Otolemur garnettii & Galagonid generalist & 2 & AMNH, MCZ & 1700 & Nash \& Harcourt, 1986 \\
\hline
\end{tabular}


Table 1. (continued)

\begin{tabular}{|c|c|c|c|c|c|}
\hline Taxon $^{\mathrm{a}}$ & Locomotory preference & $n^{\mathrm{b}}$ & Collection $^{\mathrm{c}}$ & $\begin{array}{l}\text { Body mass } \\
(\mathrm{g})\end{array}$ & Source of body mass ${ }^{\mathrm{e}}$ \\
\hline \multicolumn{6}{|l|}{ Quadrupedal/suspensory } \\
\hline $\begin{array}{l}\text { Alouatta caraya } \\
\text { (females) }\end{array}$ & Quadruped/suspensory & 3 & AMNH & 5408 & Assoc. \\
\hline Alouatta caraya (males) & Quadruped/suspensory & 4 & $\mathrm{AMNH}$ & 8546 & Assoc. \\
\hline $\begin{array}{l}\text { Alouatta palliata } \\
\text { (females) }\end{array}$ & Quadruped/suspensory & 4 & FMNH, USNM, DUPC & 5457 & 1 Ford \& Davis, 1992; 3 assoc. \\
\hline $\begin{array}{l}\text { Alouatta palliata } \\
\quad \text { (males) }\end{array}$ & Quadruped/suspensory & 12 & FMNH, USNM, DUPC & 7497 & 7 Ford \& Davis, 1992; 5 assoc. \\
\hline $\begin{array}{l}\text { Alouatta seniculus } \\
\text { (females) }\end{array}$ & Quadruped/suspensory & 7 & AMNH, FMNH, USNM & 5395 & 1 Ford \& Davis, 1992; 6 assoc. \\
\hline $\begin{array}{l}\text { Alouatta seniculus } \\
\text { (males) }\end{array}$ & Quadruped/suspensory & 4 & AMNH, FMNH & 7342 & 2 Ford \& Davis, 1992; 2 assoc. \\
\hline Ateles fusciceps & Suspensory specialist & 8 & USNM, FMNH & 9100 & 7 Ford \& Davis, 1992; 1 assoc. \\
\hline Ateles paniscus & Suspensory specialist & 2 & FMNH & 7803 & Ford \& Davis, 1992 \\
\hline $\begin{array}{l}\text { Lagothrix lagothricha } \\
\text { (females) }\end{array}$ & Quadruped/suspensory & 6 & AMNH, FMNH & 5750 & Ford \& Davis, 1992 \\
\hline $\begin{array}{l}\text { Lagothrix lagothricha } \\
\text { (males) }\end{array}$ & Quadruped/suspensory & 4 & FMNH & 8335 & Ford \& Davis, 1992 \\
\hline \multicolumn{6}{|c|}{ beneric and species names follow Simons \& Rumpler (1988) and Nash, Bearder \& Olson (1989). } \\
\hline \multicolumn{6}{|c|}{ c Source collections: American Museum of Natural History, Department of Mammalogy, New York (AMNH); } \\
\hline \multirow{6}{*}{\multicolumn{6}{|c|}{$\begin{array}{l}\text { Anthropologisches Institut und Museum der Universität Zürich-Irchel (Zurich); Field Museum of Natural History, Division of } \\
\text { Mammals (FMNH, Chicago); Natural History Museum (London); Harvard Museum of Comparative Zoology, Mammal } \\
\text { Department (MCZ, Cambridge); Muséum National d'Histoire Naturelle, Zoologie, Laboratoire Mammifères et Oiseaux, Paris } \\
\text { (MNHN); Nationaal Natuurhistorisch Museum, Rijksmuseum (Leiden); United States National Museum of Natural History, } \\
\text { Division of Mammals, Smithsonian Institution, Washington, D.C. (USNM); personal collections of K. Glander at the Duke } \\
\text { University Primate Centre, Durham, North Carolina (DUPC) and F. Vincent at the University of Paris (Nanterre). } \\
\text { d For explanation of amended body mass, see text. }\end{array}$}} \\
\hline & & & & & \\
\hline & & & & & \\
\hline & & & & & \\
\hline & & & & & \\
\hline & & & & & \\
\hline \multicolumn{6}{|c|}{ Ave. = average; assoc. = associated. } \\
\hline \multicolumn{6}{|c|}{${ }^{f}$ The Galagoides demidoff included in this sample are probably mostly G. demidoff, not G. thomasi, as they are from the } \\
\hline
\end{tabular}

and prosimian generalists. Results for comparisons of these 2 generalist subgroups are presented in Runestad (1997). When significant differences exist between subgroups for either the leapers or the generalists for a given bivariate comparison, the subgroups are left uncombined in the remaining analyses.

\section{Locomotory variation among leapers}

The indrids are among the most specialized leapers in the study (Dagosto, 1995; Warren \& Crompton, 1997). They engage in rapid ricochetal tree-to-tree leaping, with 1 leap rapidly following another (Petter, 1962; Oxnard et al., 1990). On the ground, they cover territory through large hindlimb-powered bounds (Petter, 1962) referred to (perhaps inadequately) as bipedal hopping (A. C. Walker, 1979; Gebo, 1987). Most indrids are much larger than the other leapers, ranging in body size between c. 1100 and $8000 \mathrm{~g}$ (Glander et al., 1992; Demes \& Jungers, 1993).

Tarsiers are also very hindlimb-dependent in their locomotion (Reason, 1978; Niemitz, 1979; Crompton \& Andau, 1986; Roberts \& Cunningham, 1986). Leaps as far as 50 times body length have been recorded (Crompton \& Andau, 1986). Tarsiers can travel along substrates (i.e. the ground or a tree branch) by either bipedal hopping or quadrupedal climbing (MacKinnon \& MacKinnon, 1980; Crompton \& Andau, 1986). Tarsiers are very small animals and weigh c. $120 \mathrm{~g}$ (Fogden, 1974; Bearder, 1987).

Galagonid species range in size between 60 and $1200 \mathrm{~g}$ (Charles-Dominique \& Martin, 1972; Masters, 1985), forming a progression of body sizes linking tarsiers and the smallest indrid species. The frequency of leaping $v s$ quadrupedalism in travel varies among galagonids (Charles-Dominique \& Bearder, 1979; Crompton, 1984). However, while almost all galagos are able quadrupeds, most of them (other than Otolemur) rely heavily on leaping for locomotion and can bipedally hop on horizontal substrates (Charles-Dominique, 1977; A. C. Walker, 1979; Crompton, 1984; Gebo, 1987; Harcourt \& Bearder, 1989).

Lepilemur and Hapalemur, are strong leapers (Petter \& Peyrieras, 1970b, 1975; Warren \& Crompton, 1997). They differ from each other, however, in that Hapalemur, like many galagos, is also an agile quadruped (Petter \& Peyrieras, 1970b, 1975), while Lepilemur hops bipedally when moving quickly along a continuous substrate (A. C. Walker, 1979; Oxnard et al., 1990). Both are c. $800 \mathrm{~g}$ (Glander et al., 1992; U. Thalmann, pers. comm.). 


\section{METHODS}

\section{Cross-sectional properties}

The cross-sectional properties calculated in this study are cortical area, second moments of area in coronal and sagittal planes, and polar second moment of area for a section at midshaft of the humerus and the femur. The formulae given below for calculating these properties are from Biknevicius \& Ruff (1992).

Cortical area (CA) is an estimate of the amount of bone in a cross-section, and corresponds to resistance to axial loads such as compression and tension (Burr et al., 1982). In this study, cortical area is calculated from anteroposterior (AP) and mediolateral (ML) outer (subperiosteal) and inner (medullary) bone diameters as follows:

\section{$\mathrm{CA}=[\pi \times((\mathrm{ML}$ outer diameter $\times \mathrm{AP}$ outer diameter $)-$ $(\mathrm{ML}$ inner diameter $\times \mathrm{AP}$ inner diameter $))] \div 4$}

Second moments of area $(I)$ are estimates of resistance to deformation from bending loads (Burr et al., 1982). $I_{x}$ is a measure of bending rigidity in the sagittal plane about a coronal axis. $I_{y}$ is a measure of bending rigidity in the coronal plane about a sagittal axis (Ruff \& Hayes, 1983). These properties are calculated according to the following formulae:

$I_{x}=\left[\pi \times\left(\left(\right.\right.\right.$ ML outer diameter $\times$ AP outer diameter $\left.{ }^{3}\right)-$ $\left(\mathrm{ML}\right.$ inner diameter $\times \mathrm{AP}$ inner diameter $\left.\left.\left.{ }^{3}\right)\right)\right] \div 64$

$I_{y}=\left[\pi \times\left(\left(\right.\right.\right.$ ML outer diameter ${ }^{3} \times$ AP outer diameter $)-$

(ML inner diameter ${ }^{3} \times$ AP inner diameter) $\left.)\right] \div 64$

Polar second moment of area $(J)$ is a measure of resistance to torsional forces, or twisting. In this study, $J$ is estimated by summing $I_{x}$ and $I_{y}$. As such, $J$ also functions as an estimate of average bending rigidity for a cross-section (Schaffler et al., 1985).

$\mathrm{AP}$ and ML outer and inner diameters were obtained from radiographs of the bones. Associated humeri and femora were radiographed in anteroposterior and mediolateral orientations. Subperiosteal and medullary diameters at midshaft were measured using a reflex microscope as described in Runestad et al. (1993). Radiographs of atelines were measured using a needlenosed set of callipers.

\section{Articular surface areas}

Humeral and femoral articular surface areas were calculated from linear measurements taken with digital callipers. These measurements were then entered into formulae for the areas of geometric shapes. Formulae for partial spheres were used to estimate femoral and humeral head surface areas and formulae for partial cylinders were used for humeral trochlear and capitular surface areas. The linear measurements used in calculating these areas are listed in Runestad (1997: table II). Runestad (1997: figs 1 \& 2) shows how the measurements were taken from the bones.

From Ruff (1988), the partial sphere formula for the surface area of the femoral head is:

Femoral head surface area $=(\mathrm{PD}+\mathrm{AP}) \times$ depth $\times 1.57$

where PD is the proximodistal femoral head diameter, AP is the anteroposterior diameter, and depth refers to the mediolateral width of the femoral head.

From Rafferty \& Ruff (1994), humeral head surface area is calculated using a formula which takes into account that the humeral head is often less than half of a sphere:

$$
\begin{gathered}
\text { Humeral head surface area }= \\
\pi \times\left(0.0625 \times(\mathrm{PD}+\mathrm{ML})^{2}+\mathrm{depth}^{2}\right)
\end{gathered}
$$

where PD is the proximodistal humeral head diameter, ML is the mediolateral diameter, and depth is the anteroposterior width. These terms are based on the orientation of the humerus and femur in a quadrupedal animal.

Trochlear and capitular surface areas are estimated using formulae developed by C. B. Ruff (pers. comm.):

$$
\begin{aligned}
& \text { Trochlear or capitular surface area } \\
& \quad=\text { diameter } \times \text { height } \times \text { acos }(1-2 \times \text { depth } \div \text { diameter })
\end{aligned}
$$

where diameter refers to either the AP or PD dimension, which ever is larger, and depth refers to which of the 2 is smaller. Height is the ML dimension.

For the humeral trochlea, the averages of AP and PD dimensions measured at 3 different locations are used as trochlear AP and PD dimensions in the formulae. The 3 locations are the medial lip, lateral lip, and the waisted region of the middle of the trochlea (Runestad, 1997: table II).

Unlike the other primates in the study, the small leapers - galagonids and tarsiers - have cylindrically shaped femoral heads, not spherical ones. Because of this, the standard formula for the surface area of a cylinder was used to calculate their femoral head size. This method may slightly overestimate their femoral head surface areas. Fortunately, small leapers do not have suspiciously large femoral heads relative to other primates (Fig. 7).

No articular data are included for the atelines as this group was not part of the original study.

\section{Bone length}

Femoral length was measured as the distance from the superior surface of the femoral neck to the average distal extent of the condyles (Ruff, 1987). Not including the femoral head reduces potential problems due to femoral neck angle, a more steeply inclined femoral neck would yield a longer femoral length measurement.

Humeral length was measured as the distance from the superior edge of the humeral head to the average distal extent of the trochlea and capitulum. Both the 
Table 2. Observed (obs) and effective (eff) $n$ values for multitaxa groups

\begin{tabular}{|c|c|c|c|c|c|c|}
\hline \multirow[b]{2}{*}{ Bivariate comparison } & \multicolumn{2}{|c|}{ Small leapers $^{\mathrm{a}}$} & \multicolumn{2}{|c|}{ All leapers } & \multicolumn{2}{|c|}{ Generalists $^{\mathrm{b}}$} \\
\hline & Obs $n$ & Eff $n$ & Obs $n$ & Eff $n$ & Obs $n$ & Eff $n$ \\
\hline \multicolumn{7}{|l|}{ Cross-sectional properties } \\
\hline Femoral $J /$ mass & & & 14 & 12 & 18 & 15 \\
\hline Femoral CA/mass & & & 14 & 11 & 18 & 14 \\
\hline Humeral $\mathrm{J} / \mathrm{mass}$ & & & 14 & 12 & 18 & 15 \\
\hline Humeral CA/mass & 8 & 7 & & & 18 & 15 \\
\hline Humeral $J /$ femoral $J$ & & & 14 & 11 & 18 & 11 \\
\hline Humeral CA/femoral CA & 8 & 7 & & & 18 & 10 \\
\hline Femoral CA/femoral $J$ & & & 14 & 12 & 118 & $76^{\mathrm{c}}$ \\
\hline Humeral CA/humeral $J$ & 8 & 8 & & & 18 & 14 \\
\hline Femoral $I_{y} /$ femoral $I_{x}$ & & & 14 & 13 & 18 & 16 \\
\hline Humeral $I_{y} /$ humeral $I_{x}$ & & & 14 & 12 & 18 & 12 \\
\hline \multicolumn{7}{|l|}{ Bone lengths } \\
\hline Femoral length/mass & & & 14 & 7 & 18 & 13 \\
\hline Humeral length/mass & & & 14 & 10 & 1110 & $76^{\mathrm{c}}$ \\
\hline Humeral length/femoral length & & & 14 & 11 & 117 & $77^{\mathrm{c}}$ \\
\hline \multicolumn{7}{|l|}{ Articular surface areas } \\
\hline Femoral head SA/mass & 8 & 4 & & & 18 & 16 \\
\hline Humeral head SA/mass & & & 14 & 8 & 18 & 16 \\
\hline Humeral head SA/femoral head SA & 8 & 6 & & & 18 & 10 \\
\hline Capitular SA/mass & 8 & 3 & & & 18 & 14 \\
\hline Trochlear SA/mass & 8 & 7 & & & 18 & 16 \\
\hline Capitular SA/trochlear SA & 8 & 5 & & & 18 & 16 \\
\hline
\end{tabular}

${ }^{\text {a }}$ Effective $n$ values for the small leapers were only calculated for those comparisons including properties where small and large leapers differ using the observed $n$ values, such as humeral CA.

${ }^{\mathrm{b}}$ Most of the generalist data are also presented in Runestad (1997).

${ }^{\mathrm{c}}$ For these properties, platyrrhine and prosimian generalists differ and are kept separate. Platyrrhine data are given first,

followed by data for the prosimian generalists.

Table 3. Significant allometry with reduced major axis (RMA) slopes ${ }^{a}$

\begin{tabular}{|c|c|c|c|c|c|c|}
\hline \multirow[b]{2}{*}{ Group } & \multirow{2}{*}{$\begin{array}{l}\text { Property regressed } \\
\text { on body mass }\end{array}$} & \multirow[b]{2}{*}{ RMA slope } & \multirow[b]{2}{*}{ RMA intercept } & \multirow{2}{*}{$\begin{array}{l}\text { Direction of } \\
\text { allometry }\end{array}$} & \multicolumn{2}{|c|}{ Significance level } \\
\hline & & & & & Obs $n$ & Eff $n$ \\
\hline \multirow[t]{4}{*}{ Generalists } & Femoral $J$ & 1.50 & -6.26 & Positive & $* * *$ & $* *$ \\
\hline & Femoral CA & 0.81 & -3.06 & Positive & $* *$ & $* *$ \\
\hline & Humeral $J$ & 1.54 & -6.83 & Positive & $* * *$ & $* * *$ \\
\hline & Humeral CA & 0.83 & -3.33 & Positive & $* * *$ & $* *$ \\
\hline \multirow[t]{2}{*}{ Big leapers } & Humeral CA & 0.78 & -3.27 & Positive & $*$ & \\
\hline & Trochlear SA & 0.77 & -1.64 & Positive & $*$ & \\
\hline \multirow[t]{2}{*}{ All leapers } & Femoral $J$ & 1.42 & -5.20 & Positive & $* *$ & $* *$ \\
\hline & Femoral CA & 0.74 & -2.29 & Positive & $*$ & $*$ \\
\hline \multirow[t]{9}{*}{ Lemurids } & Femoral $J$ & 1.94 & -9.43 & Positive & $* * *$ & \\
\hline & Femoral CA & 1.12 & -5.39 & Positive & $* *$ & \\
\hline & Humeral $J$ & 2.60 & -15.21 & Positive & $* * *$ & \\
\hline & Humeral CA & 1.35 & -7.58 & Positive & $* *$ & \\
\hline & Humeral length & 0.59 & -0.11 & Positive & $* *$ & \\
\hline & Femoral head SA & 1.27 & -4.16 & Positive & $* *$ & \\
\hline & Humeral head SA & 1.44 & -5.81 & Positive & $* *$ & \\
\hline & Capitular SA & 1.87 & -10.27 & Positive & $* *$ & \\
\hline & Trochlear SA & 1.38 & -6.03 & Positive & $*$ & \\
\hline \multirow[t]{3}{*}{ Atelines } & Femoral $J$ & 2.22 & -12.53 & Positive & $* *$ & \\
\hline & Humeral $J$ & 1.82 & -9.14 & Positive & $* *$ & \\
\hline & Humeral CA & 0.91 & -4.08 & Positive & $*$ & \\
\hline
\end{tabular}

${ }^{a}$ Only results that differ significantly from isometry are reported.

${ }^{\mathrm{b}} J=$ polar second moment of area for midshaft; CA = cortical area for midshaft; $\mathrm{SA}=$ articular surface area. 
femur and humerus were measured parallel to the diaphyseal long axis.

\section{Analytical techniques}

Species averages are used as data points, with some sexually dimorphic species also divided by sex (i.e. several platyrrhines). The species averages were transformed by natural logarithm to accommodate the body mass range included in the sample. For all statistical analyses, an $\alpha$ of 0.05 is required for significance.

Diaphyseal cross-sectional properties, articular surface areas and bone lengths are regressed on body mass for each locomotory subgroup and group. Humeral properties are also regressed on corresponding femoral ones, $I_{y}$ is regressed on $I_{x}$ for both the femur and humerus, and capitular surface area is regressed on trochlear surface area. Regressions of femoral and humeral $I_{y}$ and $I_{x}$ on body mass are not statistically analysed, as such comparisons do not notably differ from femoral or humeral $J$ regressed on body mass (Runestad, 1994). All bivariate comparisons were evaluated for whether or not they showed significant correlations between the 2 properties compared for each group. It was found that all regressions are significant except for the ateline regression of femoral length on body mass.

The data were fit using both least squares (LS) (SYSTAT: Wilkinson, 1992) and reduced major axis (RMA) techniques (Hofman, 1988). Most of the correlation coefficients in this analysis are well above 0.95 . However, many coefficients for the lemurids and atelines are much lower, and analyses using RMA slopes often yield different results than for LS slopes for these groups (see Tables $5 \& 6$ ).

For each locomotory group or subgroup consisting of $>1$ family, the degrees of freedom are modified to account for the possibility that some members of a locomotory group may be more similar to each other than to others in the group as a result of common ancestry. A nested analysis of variance procedure (BIOM: Rohlf \& Slice, 1995) was used to arrive at an 'effective $n$ ' estimate (Smith, 1994: 99). The groups were nested at the suborder (when appropriate), family and genus levels.

It was necessary to nest residuals of bivariate comparisons instead of nesting the properties themselves because many of the taxonomic groups within the locomotory groups differ from each other in body size (Smith, 1994; Runestad, 1997). For each sample, all species were used to calculate the residuals.

Table 2 shows the observed (number of species) and effective (calculated) sample sizes for bivariate regressions for each multi-family group. Most of the generalist data are also presented in Runestad (1997). Exceptions are humeral and femoral bivariate regressions of $I_{y}$ on $I_{x}$, which are new to this analysis.

Slopes for bivariate regressions of properties on body mass were tested for allometric patterns using the RMA line-fitting technique following formulae in Hofman (1988). Significant deviations from isometry are shown in Table 3.

The bivariate LS slopes of different locomotory groups (and subgroups) are compared with each other using ANCOVA (SYSTAT: Wilkinson, 1992). RMA slopes for different groups are also compared using the Student's t-statistic and degrees of freedom derived from formulae in Hofman (1988). Results are shown in Tables 4-6.

Elevations, or positions, of regression lines are compared using ANCOVA (SYSTAT: Wilkinson, 1992) if LS slopes do not differ. Fisher's exact test, as described in Tsutakawa \& Hewett (1977), is also used to test for positional differences (SYSTAT: Wilkinson, 1992).

The advantage of the exact test is that, unlike ANCOVA elevation comparisons, it can be used when slopes differ. It involves fitting a common line through the data point of 2 samples and counting the number of points above and below the line for both samples. Results of the positional tests are shown in Tables 4-6.

The disadvantage of using Fisher's exact test for positional differences is that it assumes that the data points of the 2 samples overlap in range. This limitation seriously affects results for many comparisons. For example, it is not possible to compare small and large leapers, nor generalists and atelines, because their data points do not overlap.

To contend with this problem, the broader samples were restricted to members overlapping in body size with the more restricted samples for Fisher's exact test (see Tables 4-6). Thus, for comparisons where large and small leapers had previously been shown to differ, only the 5 biggest generalists are compared to large leapers, and the 7 smallest generalists are compared to the small leapers. Lemurids are only compared to the large leapers and to the 5 biggest generalists. This approach does produce artificially defined generalist subsamples for which no effective $n$ values are provided. However, when comparisons are possible, significance levels for the exact test are almost always lower than for the ANCOVA elevation tests (Tables 4-6).

\section{RESULTS}

\section{Subgroup comparisons}

Small leapers and large leapers differ in humeral cortical area (CA) relative to body mass, femoral head surface area relative to body mass, and capitular surface area relative to trochlear surface area. Large leapers have lower humeral axial rigidity, larger femoral heads and larger capitula relative to trochleae than do small leapers. Small leapers and large leapers are not combined for comparisons with other locomotory groups that involve humeral cortical area, femoral head surface area, capitular surface area or trochlear surface area.

Differences between the generalist subgroups (platyrrhines and prosimian generalists) are presented in 
Table 4. Leapers $v s$ generalists: bivariate slope and elevation comparisons

\begin{tabular}{|c|c|c|c|c|c|c|c|c|}
\hline \multirow[t]{2}{*}{ Bivariate comparisons for leapers $v s$ generalists $^{\mathrm{a}}$} & \multicolumn{2}{|c|}{ RMA slopes } & \multicolumn{2}{|c|}{ LS slopes } & \multicolumn{2}{|c|}{$\begin{array}{l}\text { ANCOVA } \\
\text { elevations }\end{array}$} & \multicolumn{2}{|c|}{$\begin{array}{l}\text { Fisher's exact } \\
\text { test elevations }{ }^{b}\end{array}$} \\
\hline & Obs & Eff & Obs & Eff & Obs & Eff & Obs & Eff \\
\hline Femoral $\mathrm{J} /$ mass & \multicolumn{2}{|c|}{ NS } & \multicolumn{2}{|c|}{ NS } & $* * *$ & $* * *$ & $* * *$ & $* * *$ \\
\hline Femoral CA/mass & \multicolumn{2}{|c|}{ NS } & \multicolumn{2}{|c|}{ NS } & $* * *$ & $* * *$ & $* * *$ & $* * *$ \\
\hline Humeral $\mathrm{J} /$ mass & $* * *$ & $* *$ & $*$ & $*$ & & & \multicolumn{2}{|c|}{ NS } \\
\hline \multicolumn{9}{|l|}{ Humeral CA/mass } \\
\hline Large leapers $v s$ & \multicolumn{2}{|c|}{ NS } & \multicolumn{2}{|c|}{ NS } & $* *$ & $* *$ & \multicolumn{2}{|c|}{$\begin{array}{l}* \text { vs } 5 \text { biggest } \\
\text { generalists }\end{array}$} \\
\hline Small leapers $v s$ & \multicolumn{2}{|c|}{ NS } & \multicolumn{2}{|c|}{ NS } & \multicolumn{2}{|c|}{ NS } & \multicolumn{2}{|c|}{$\begin{array}{l}\text { NS vs } 7 \text { smallest } \\
\text { generalists }\end{array}$} \\
\hline \multicolumn{9}{|l|}{ Humeral CA/femoral CA } \\
\hline Large leapers $v s$ & \multicolumn{2}{|c|}{ NS } & \multicolumn{2}{|c|}{ NS } & $* * *$ & $* * *$ & \multirow{2}{*}{\multicolumn{2}{|c|}{$\begin{array}{l}* * \text { vs } 5 \text { biggest } \\
\text { generalists } \\
* * * \text { vs } 7 \text { smallest } \\
\text { generalists }\end{array}$}} \\
\hline Small leapers $v s$ & \multicolumn{2}{|c|}{ NS } & \multicolumn{2}{|c|}{ NS } & $* * *$ & $* * *$ & & \\
\hline Humeral $J /$ femoral $J$ & $*$ & NS & & & $* * *$ & $* * *$ & $* * *$ & $* * *$ \\
\hline $\begin{array}{l}\text { Femoral CA/femoral } J \\
v s \text { platyrrhines }\end{array}$ & & & $*$ & $*$ & & & & NS \\
\hline vs prosimian generalists & & & & & & & & \\
\hline Humeral CA/humeral $J$ & & & & & & & & \\
\hline Large leapers $v s$ & & & & & $* * *$ & $* * *$ & $\begin{aligned} * v s \\
\mathrm{ge}\end{aligned}$ & $\begin{array}{l}\text { gest } \\
\text { alists }\end{array}$ \\
\hline Small leapers $v s$ & & & & & & & $\begin{array}{l}\mathrm{NS} \\
\mathrm{ge}\end{array}$ & $\begin{array}{l}\text { smallest } \\
\text { alists }\end{array}$ \\
\hline Femoral $I_{y} /$ femoral $I_{x}$ & & & & & $* * *$ & $* * *$ & $* * *$ & $* * *$ \\
\hline Humeral $I_{y} /$ humeral $I_{x}$ & & & & & $* * *$ & $* * *$ & $* *$ & $*$ \\
\hline Femoral length/mass & & & & & $* * *$ & $* * *$ & $* * *$ & $* *$ \\
\hline Humeral length/mass & & & & & & & & \\
\hline vs platyrrhines & & & & & $* * *$ & $* * *$ & $* * *$ & $* *$ \\
\hline$v s$ prosimian generalists & & & & & & & & \\
\hline Humeral length/femoral length & & & & & & & & \\
\hline vs platyrrhines & & & & & $* * *$ & $* * *$ & $* * *$ & $* * *$ \\
\hline$v s$ prosimian generalists & & & & & $* * *$ & $* * *$ & $* *$ & $*$ \\
\hline Femoral head SA/mass & & & & & & & & \\
\hline Large leapers $v s$ & & & & & $* * *$ & $* * *$ & $\begin{array}{rl}* * & v \\
\mathrm{ge}\end{array}$ & $\begin{array}{l}\text { iggest } \\
\text { alists }\end{array}$ \\
\hline Small leapers $v s$ & & & & & & & $\mathrm{NS}$ & $\begin{array}{l}\text { smallest } \\
\text { alists }\end{array}$ \\
\hline Humeral head SA/mass & & & $*$ & $*$ & & & & JS \\
\hline Humeral head SA/femoral head SA & & & & & & & & \\
\hline Large leapers $v s$ & & & & & $* * *$ & $* * *$ & $\begin{array}{rl}* * & v \\
\mathrm{ge}\end{array}$ & $\begin{array}{l}\text { iggest } \\
\text { alists }\end{array}$ \\
\hline Small leapers $v s$ & & & & & & & $\mathrm{NS}$ & $\begin{array}{l}\text { smallest } \\
\text { alists }\end{array}$ \\
\hline Capitular SA/mass & & & & & & & & \\
\hline Large leapers $v s$ & & & & & & & $\begin{array}{r}\mathrm{NS} \\
\mathrm{ge}\end{array}$ & $\begin{array}{l}\text { biggest } \\
\text { alists }\end{array}$ \\
\hline Small leapers $v s$ & & & & & & & $\mathrm{NS}$ ge & $\begin{array}{l}\text { smallest } \\
\text { alists }\end{array}$ \\
\hline Trochlear SA/ mass & & & & & & & & \\
\hline Large leapers $v s$ & & & & & $*$ & $*$ & $\begin{array}{rl}* * & v \\
\mathrm{ge}\end{array}$ & $\begin{array}{l}\text { iggest } \\
\text { alists }\end{array}$ \\
\hline Small leapers $v s$ & & & & & & & $\mathrm{NS}$ & $\begin{array}{l}\text { smallest } \\
\text { alists }\end{array}$ \\
\hline Capitular SA/ trochlear SA & & & & & & & & \\
\hline Large leapers $v s$ & $*$ & $*$ & & & $* * *$ & $* * *$ & $\begin{array}{r}\mathrm{NS} \\
\mathrm{ge}\end{array}$ & $\begin{array}{l}\text { biggest } \\
\text { alists }\end{array}$ \\
\hline Small leapers $v s$ & & & & & & & $\mathrm{NS}$ & $\begin{array}{l}\text { smallest } \\
\text { alists }\end{array}$ \\
\hline
\end{tabular}

${ }^{\mathrm{a}} J=$ polar second moment of area; $\mathrm{CA}=$ cortical area; $I_{x}$ and $I_{y}$ are second moments of area; $\mathrm{SA}=$ articular surface area.

$\mathrm{b}$ The elevation test using Fisher's exact test relies on two samples having roughly similar ranges. When this was not possible, as with comparisons involving only the large leapers or the small leapers, the generalist sample was restricted to those data points overlapping with the relevant leaper subsample.

Significance levels: $* \leq 0.05 ; * * \leq 0.01 ; * * * \leq 0.001 ; \mathrm{NS}$, not significant.

RMA = reduced major axis; $\mathrm{LS}=$ least squares; Obs = with observed sample size; Eff $=$ with effective sample size $($ see text $)$. 
Table 5. Significant results of bivariate slope and elevation tests for secondary leaper comparisons

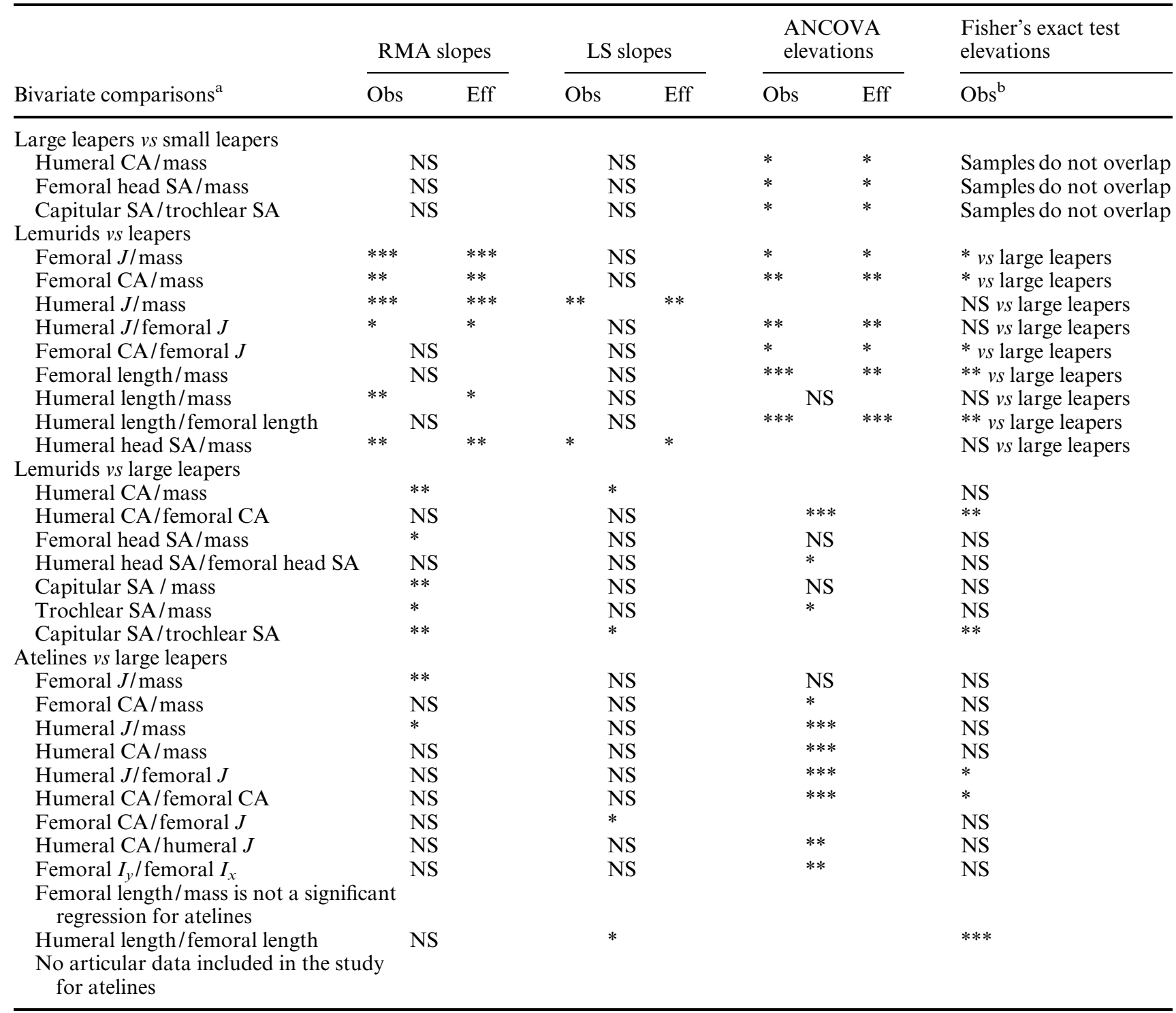

${ }^{\mathrm{a}} J=$ polar second moment of area; $\mathrm{CA}=$ cortical area; $I_{x}$ and $I_{y}$ are second moments of area; SA = articular surface area.

${ }^{b}$ The elevation test using Fisher's exact test relies on two samples having roughly similar ranges. As this was not possible with the leapers and lemurids, the leaper sample was restricted to those leaper data points overlapping with the lemurid data. Note also that only the small leapers and the total leapers samples have effective $n$ values. This is because the members of the other groups are restricted to one family each.

Significance levels, $* \leq 0.05 ; * * \leq 0.01 ; * * * \leq 0.001 ; \mathrm{NS}$, not significant.

$\mathrm{RMA}=$ reduced major axis; $\mathrm{LS}=$ least squares; $\mathrm{Obs}=$ with observed sample size; $\mathrm{Eff}=$ with effective sample size $($ see text $)$.

Runestad (1997). The two subgroups differ in femoral cortical area relative to femoral polar second moment of area $(J)$, humeral length relative to body mass, and humeral length relative to femoral length. Properties new with the present analysis, humeral and femoral $I_{x}$ and $I_{y}$, do not differ between the two subgroups.

\section{Allometry}

Table 3 shows equations for properties regressed on body mass for which RMA slopes differ significantly from isometry. All significant departures are positively allometric. There is a general pattern for humeral and femoral cross-sectional properties (cortical area and $J$ ) to increase at a greater rate than that expected from geometric similarity for most of the locomotory groups. This trend is probably statistically more reliable for the larger samples, the generalists and leapers.

Among the smaller samples, lemurids show positive allometry for most properties: humeral and femoral cortical area and $J$, articular surface areas, and humeral length. However, Varecia is relatively large in most of these properties and, as the largest lemurid, may be strongly affecting slopes.

Atelines are another small sample which shows positive allometry for cross-sectional properties. This 
Table 6. Significant results of bivariate slope and elevation tests for secondary generalists comparisons

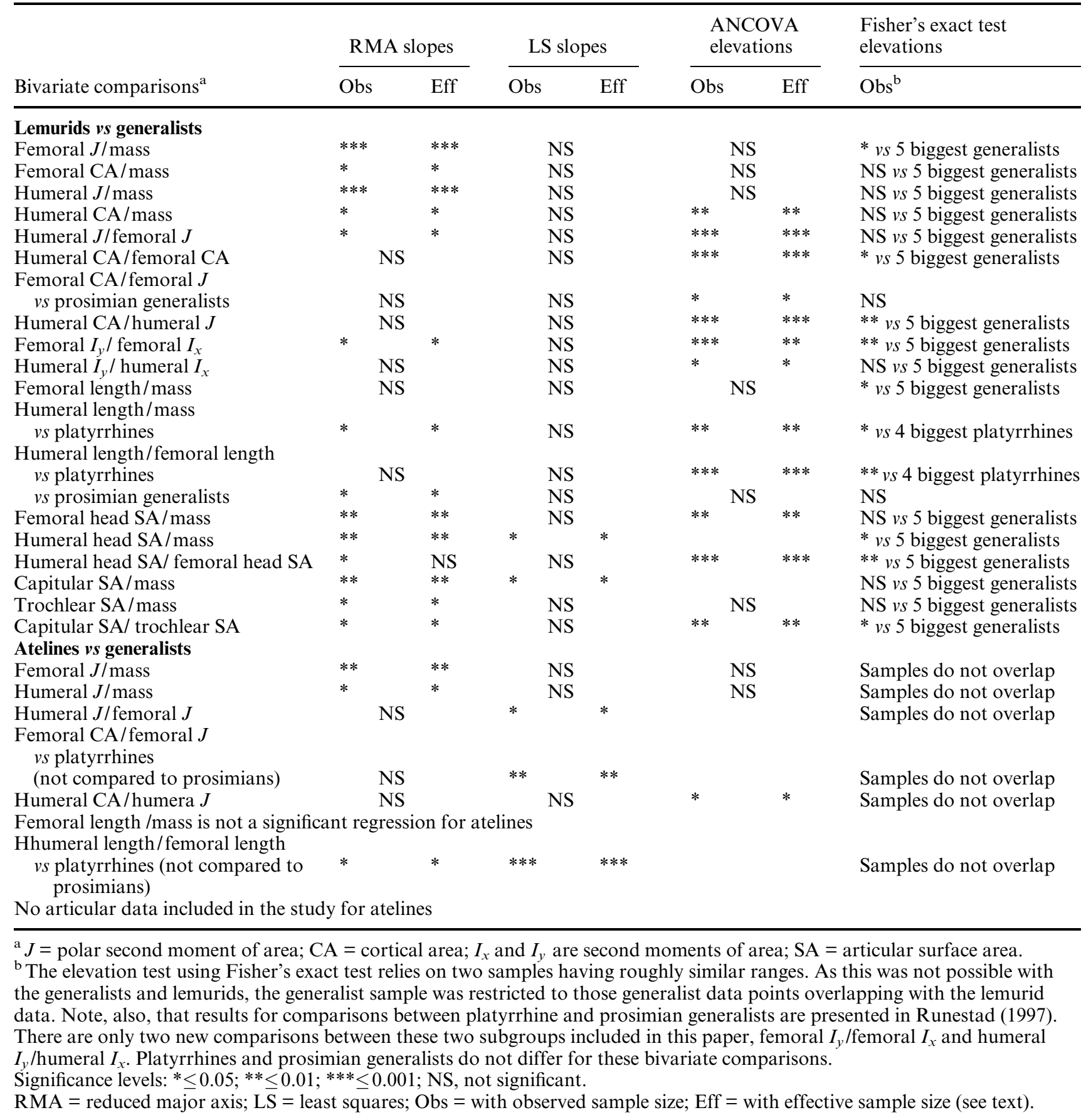

may partially result from the inclusion of highly suspensory Ateles species with more generalized atelines.

\section{Comparisons of locomotory groups}

\section{Cross-sectional properties}

Intergroup comparisons are split into three tables. Table 4 displays the comparisons of all leapers $v s$ generalists. Table 5 shows significant differences between leapers and secondary groups: lemurids and atelines. Table 6 shows significant differences between generalists and the secondary groups.

Leapers have greater femoral $J$ and cortical area than do generalists, as indicated by highly significant elevation differences between the groups (Table 4), and by their relative positions in Fig. 1, femoral $J$ vs body mass, and Fig. 2, femoral cortical area vs body mass. Leapers also have greater femoral cross-sectional properties than do lemurids (Table 5). Lemurids lie between leapers and generalists in Fig. 1, and close to the generalists in Fig. 2. Apparently, lemurids have slightly greater femoral $J$, but not cortical area, than generalists 


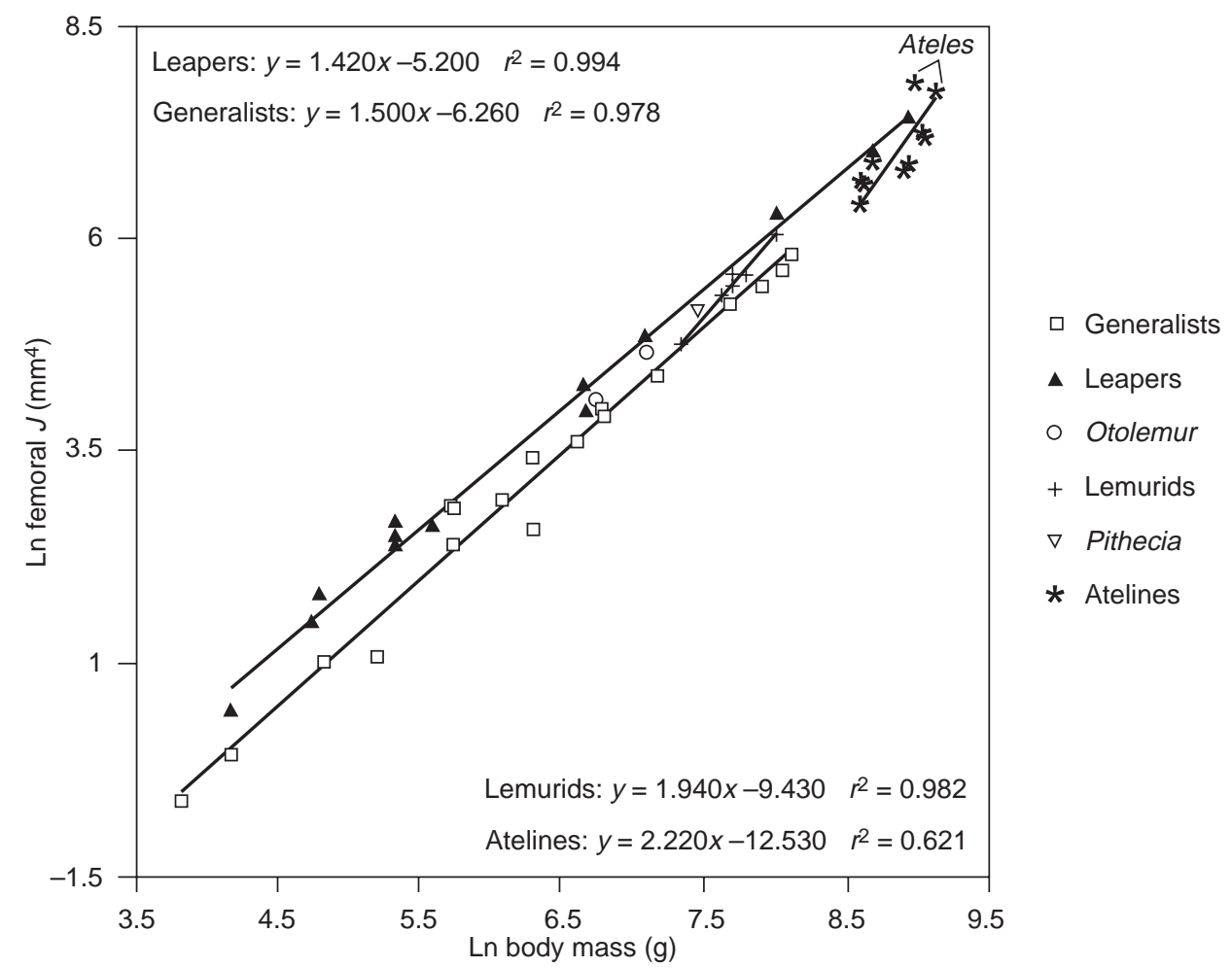

Fig. 1. Bivariate plot of femoral polar second moment of area $v s$ body mass. The line-fitting technique is reduced major axis.

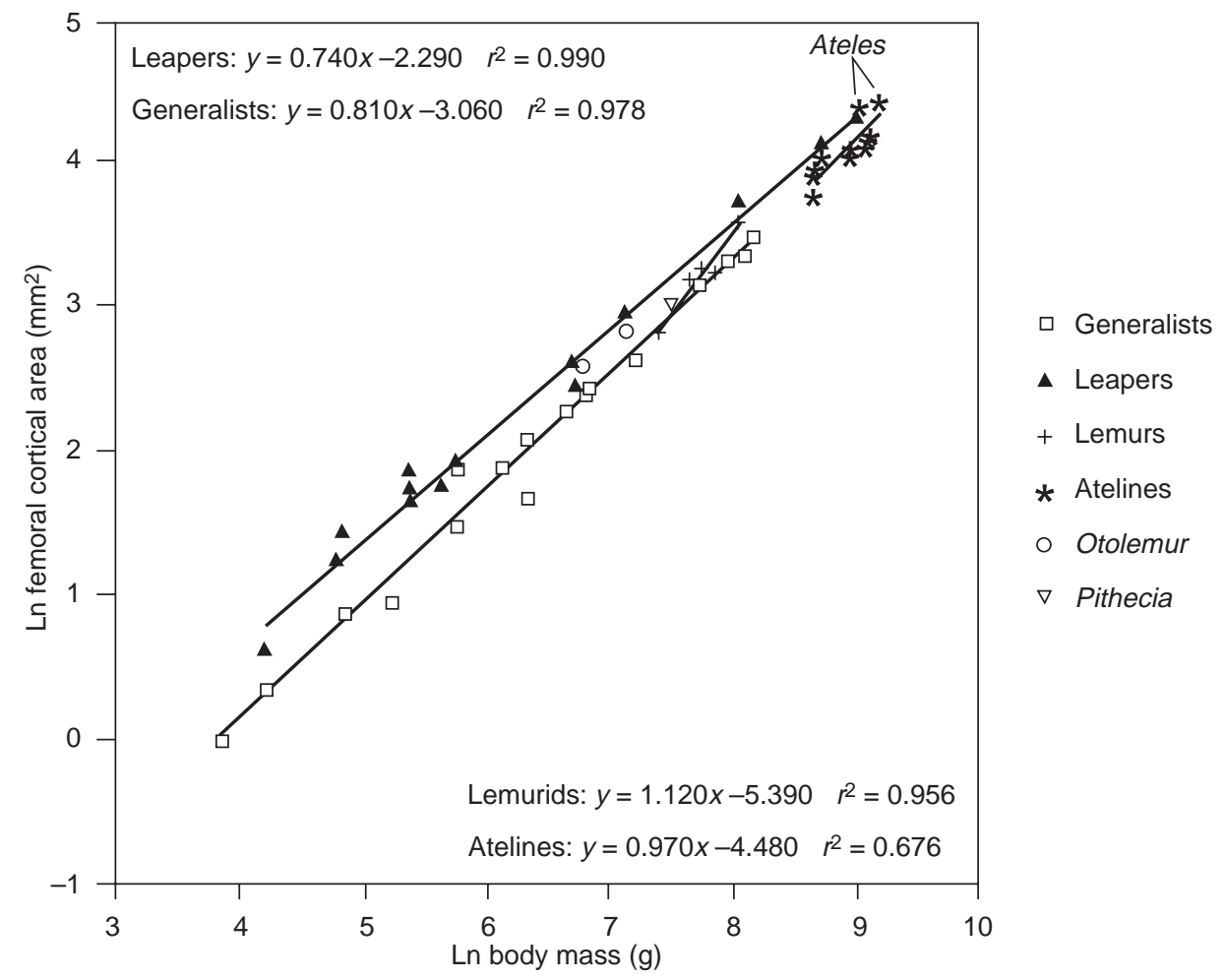

Fig. 2. Bivariate plot of femoral cortical area $v s$ body mass. The line-fitting technique is reduced major axis.

(Table 6). Altogether, leaper femora are more resistant to both axial and torsional loads than are either generalist or lemurid femora, and lemurid femora are stronger than those of generalists against torsional/ bending forces.
Compared to atelines, leapers have only slightly greater femoral cortical area, and similar femoral $J$, as reflected by elevation comparisons (Table 5). This may be a result, however, of the large cross-sectional values of Ateles within the atelines, and the low correlation of 


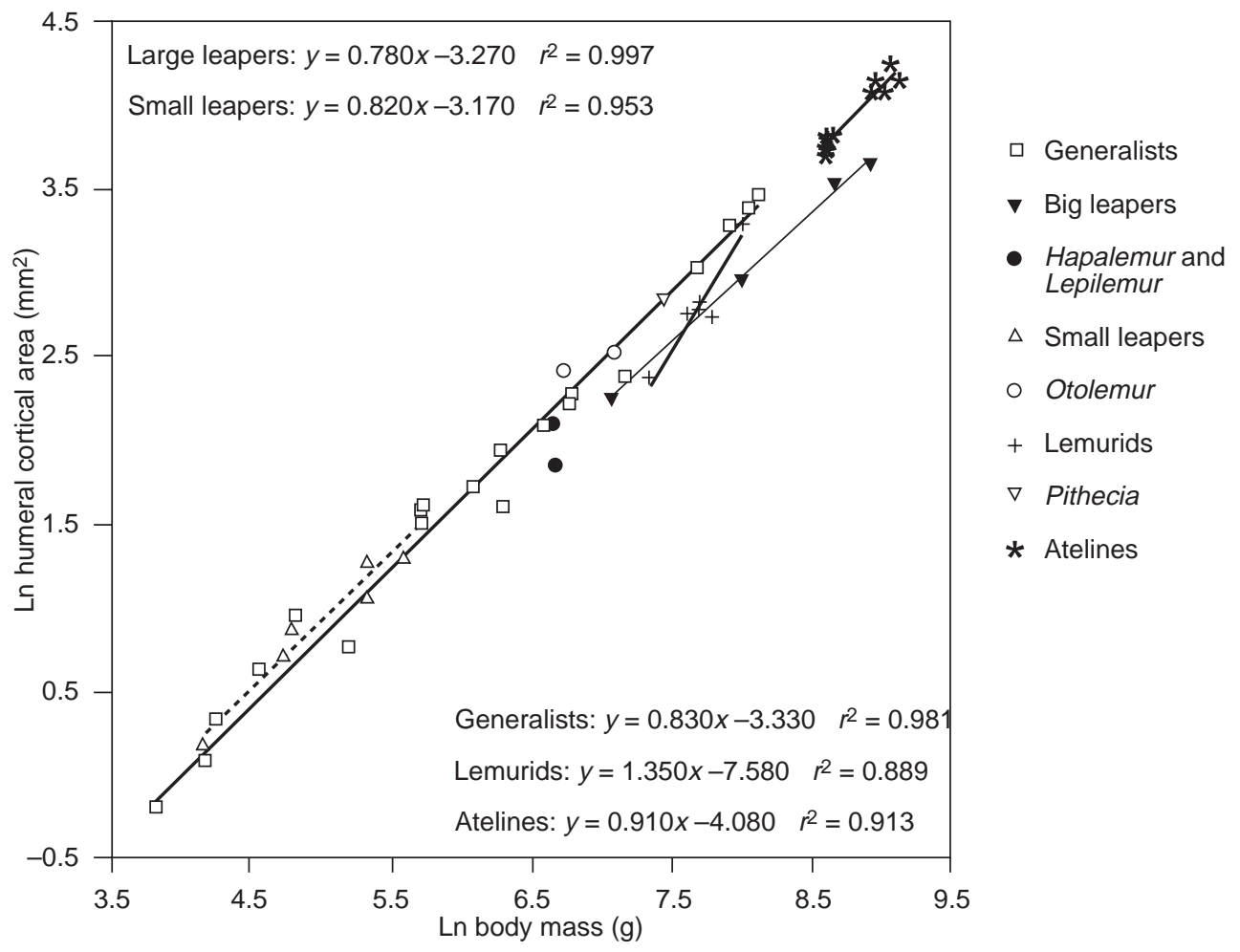

Fig. 3. Bivariate plot of humeral cortical area $v s$ body mass. The line-fitting technique is reduced major axis.

ateline regressions. Figures $1 \& 2$ clearly show that the leaper regressions for femoral $J$ on body mass and femoral cortical area on body mass lie above most of the atelines.

Pithecia and the two Otolemur species are shown in Figs $1 \& 2$. In Fig. 1, femoral $J$ on body mass, all three taxa lie between the generalists and the leapers, although Pithecia lies slightly closer to the leapers than do the large galagos. In Fig. 2, femoral cortical area $v s$ body mass, Pithecia lies close to the other platyrrhines, and well away from the other leapers. The position of Otolemur species is roughly similar in both Figs 1 \& 2, indicating that Otolemur has femoral cross-sectional properties intermediate between leapers and generalists. Pithecia has relatively greater torsional or bending rigidity than most of the other small platyrrhines, but not greater axial rigidity.

Femoral cortical area regressed on femoral $J$ indicates that leapers and prosimian generalists have relative thicker femoral diaphyses than do platyrrhine generalists (Table 4) and lemurids (Tables 5 \& 6). Leapers do not differ from prosimian generalists (Table 4).

For the remaining femoral cross-sectional bivariate comparison, femoral $I_{y} v s$ femoral $I_{x}$, leapers have greater $I_{x}$ relative to $I_{y}$ than do generalists and atelines (Tables 4 \& 5). Lemurids are also greater in this property than are generalists (Table 6). Leapers and lemurids do not differ. Leaper and lemurid femora appear to be more buttressed against bending forces about a coronal axis, acting in a sagittal plane. Essentially, this means that their femoral midshaft AP diameters are larger than their ML ones, relative to the proportions seen in generalists and atelines (see formulae in Methods). This interpretation is supported by examination of bivariate plots of both $I_{y}$ and $I_{x}$ regressed on body mass (not shown).

The relative positions of Pithecia and Otolemur on plots of femoral or humeral $I_{x}$ regressed on $I_{y}$ are not considered in this analysis. This is because the regression lines for leapers and generalists are very close together, suggesting that the positions of individual data points may be open to over-interpretation (see Runestad, 1994: Fig. 6).

For humeral cross-sectional properties, humeral $J$ does not differ between any groups in elevation except for between large leapers and atelines (Table 5). Ateline humeri appear to be more resistant to bending or torsional forces than are large leaper humeri, according to the relative positions of the groups in a bivariate plot of humeral $J v s$ body mass (not shown).

For humeral cortical area $v s$ body mass, small leapers, generalists and atelines all have significantly higher elevations than do large leapers (Tables $4 \& 5$, Fig. 3). Generalists also have greater humeral cortical area than do lemurids (Table 6), although the largest lemurid, Varecia, lies on the generalist line (Fig. 3). Generalists do not differ from either small leapers or atelines (Tables 4 \& 6). Most taxa not included within a locomotory group for this comparison - Hapalemur, Otolemur and Pithecia - group with the generalists in Fig. 3. Lepilemur seems to group with the lemurids and large leapers (although see comments below). In 


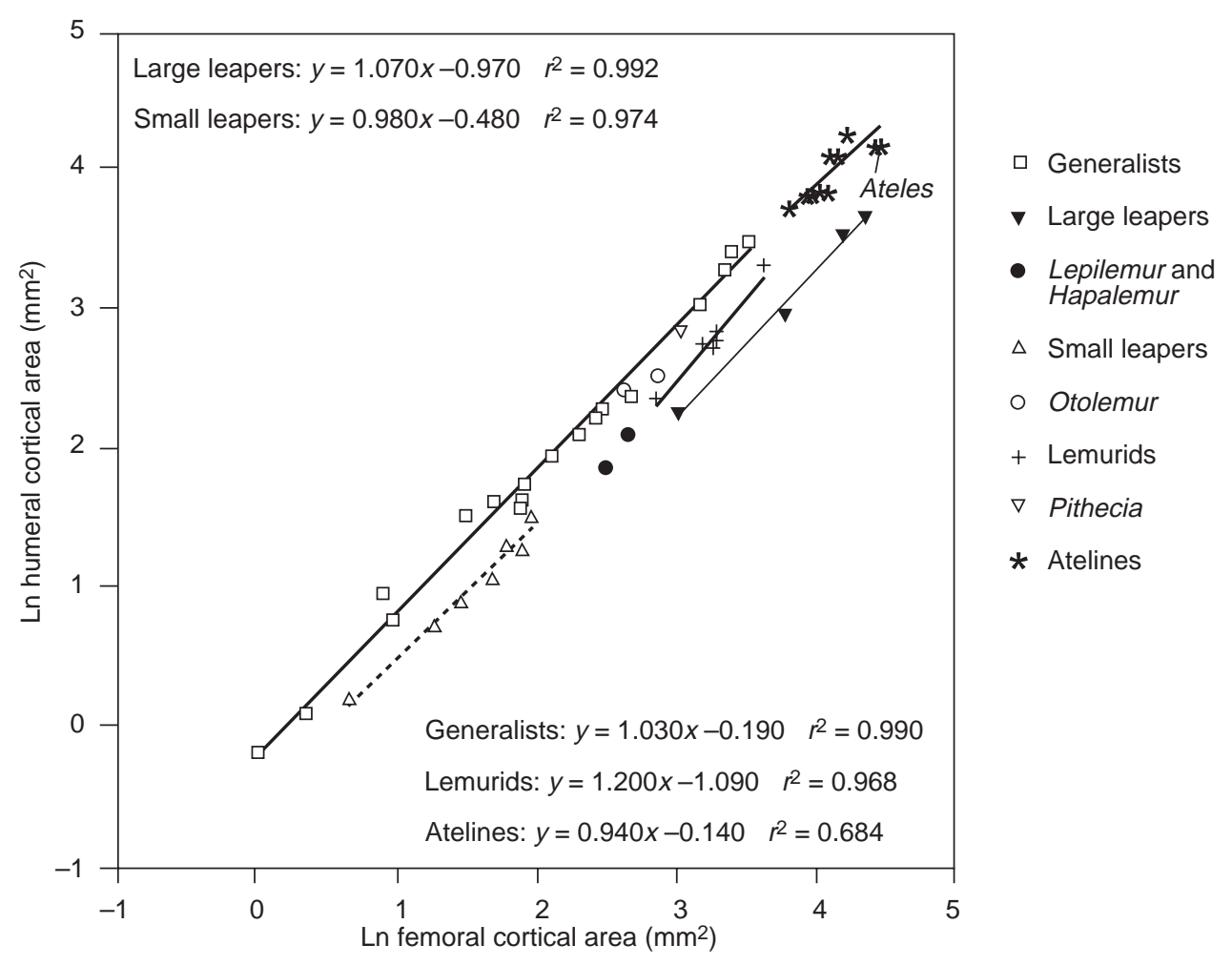

Fig. 4. Bivariate plot of humeral cortical area $v s$ femoral cortical area. The line-fitting technique is reduced major axis.

summary, the humeri of most lemur-like ${ }^{1}$ primates (large leapers, lemurids and Lepilemur) may be relatively weak in resistance to axial loads.

Lepilemur's position on bivariate comparisons involving body mass should not be over-interpreted. Lepilemur consistently falls below Hapalemur in most property $v s$ body mass regressions (see Figs $1-3,5-10$ ), where it can be identified as either the ninth leaper in body mass, or the slightly heavier data point of the combined Hapalemur/Lepilemur grouping. However, Lepilemur aligns with Hapalemur and the other leapers in bivariate regressions not involving body mass (see Figs $4 \& 11$ ). Therefore, it is probable that the assigned body mass is far too large. This unassociated mass is from a very small sample of wild-caught Lepilemur, and may not be a representative average for the species.

Humeral cortical area regressed on humeral $J$ shows

\footnotetext{
${ }^{1}$ The term 'lemur-like' is used to refer to all primates having strong morphological resemblences to lemurids. Such primates include indrids, lemurids, Hapalemur and Lepilemur, which are similar in many aspects of their anatomy (Gebo, 1986; Tattersall \& Schwartz, 1991; J. R. Connour, pers. obs.), and exclude cheirogaleids (which resemble galagonids in many respects. Charles-Dominique \& Martin, 1972; Gebo, 1986; J. R. Connour, pers. obs.) and Daubentonia. It is necessary to avoid using terms with phylogenetic meaning, such as lemuroid or lemuriform, for the lemur-like grouping, bacause recent molecular and dental evidence raises the possibility that cheirogaleids and lemurids may be more closely related than either are to indrids (Dutrillaux \& Rumpler, 1995; Yoder et al., 1996).
}

patterns similar to humeral cortical area regressed onbody mass. Generalists and atelines have relatively higher values of humeral cortical area relative to humeral $J$ than do large leapers (Tables $4 \& 5$ ). Generalists are also greater than lemurids and atelines in elevation for this comparison (Table 6). However, for lemurids, this is because of a relatively low cortical area (Fig. 3), while for atelines it is a result of relatively high (but not significantly so) humeral $J$ compared to generalists.

In summary, large leapers and lemurids are characterized by humeral $J$ values that are similar to those expected for primates of their size, but humeral cortical area levels that are low relative to the other primates in the study.

The last humeral cross-sectional comparison is humeral $I_{y}$ vs $I_{x}$. Leapers and lemurids differ from generalists in elevation (Tables $4 \& 6$ ). Leapers and lemurids have relatively lower $I_{y}$ relative to $I_{x}$ than do generalists, suggesting less resistance to bending about a sagittal axis in a coronal plane. Bivariate plots of $I_{y}$ on body mass, and $I_{x}$ on body mass (not shown) support this interpretation, although the difference seems to be mostly between bigger leapers (indrids, Hapalemur and Lepilemur) and generalists, rather than between the small leapers and generalists. Generalists may be more resistant to humeral loading which, if unchecked, would cause 'sideways' bending.

To compare properties without using body mass, humeral $J$ is regressed on femoral $\mathrm{J}$, and humeral cortical area is regressed on femoral cortical area. Leapers are highly significantly different for both 


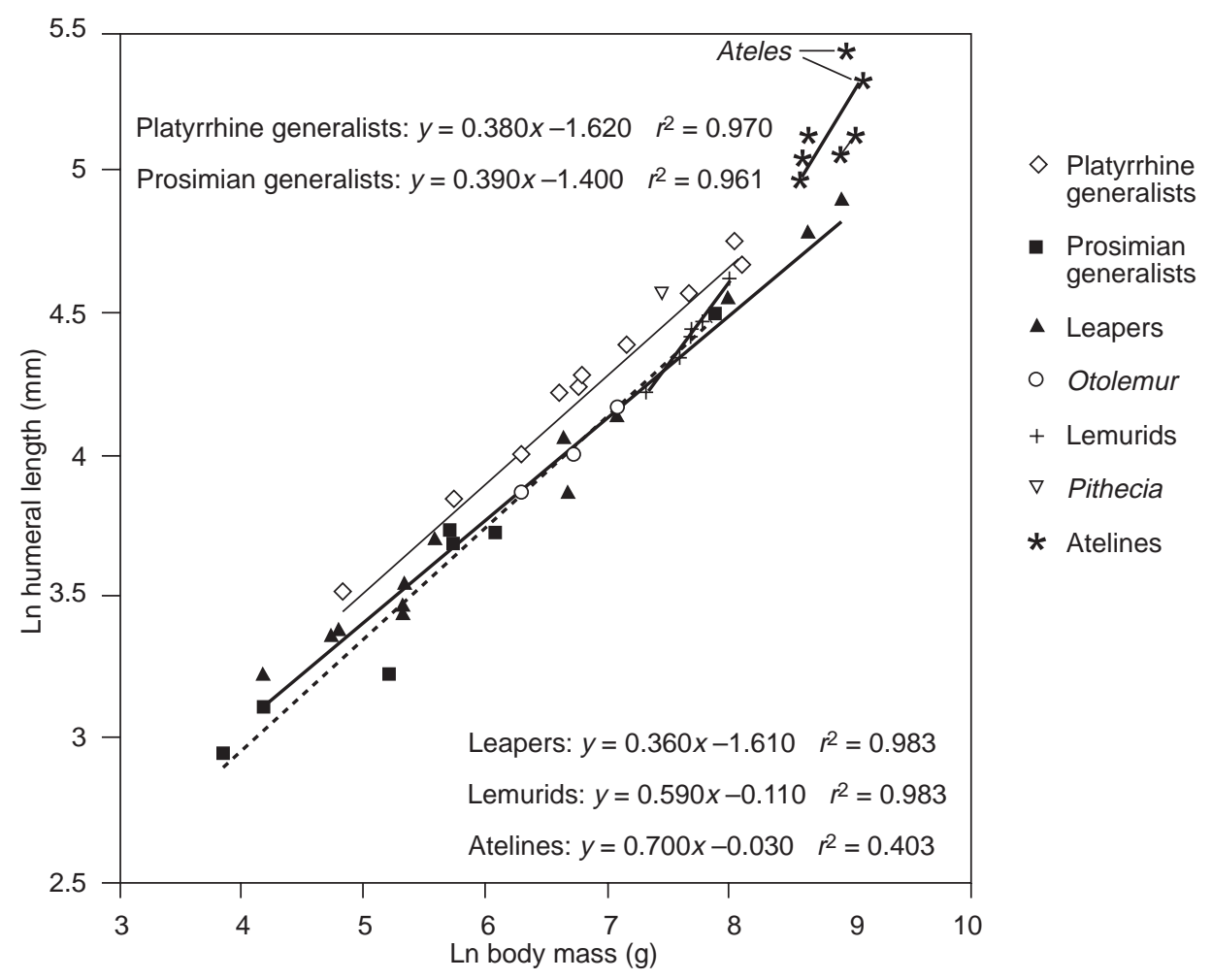

Fig. 5. Bivariate plot of humeral length $v$ body mass. The line fitting technique is reduced major axis.

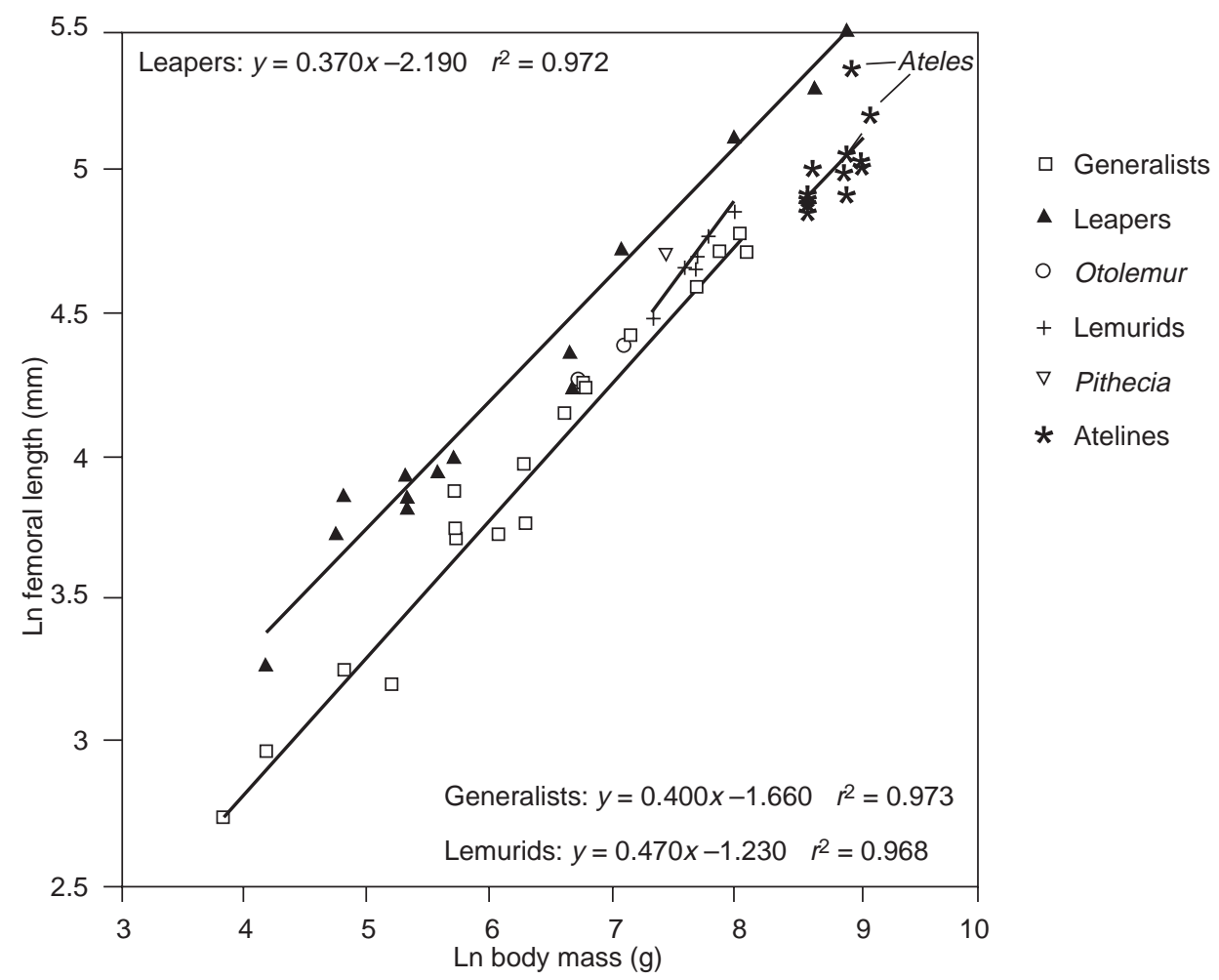

Fig. 6. Bivariate plot of femoral length $v s$ body mass. The line-fitting technique is reduced major axis. 


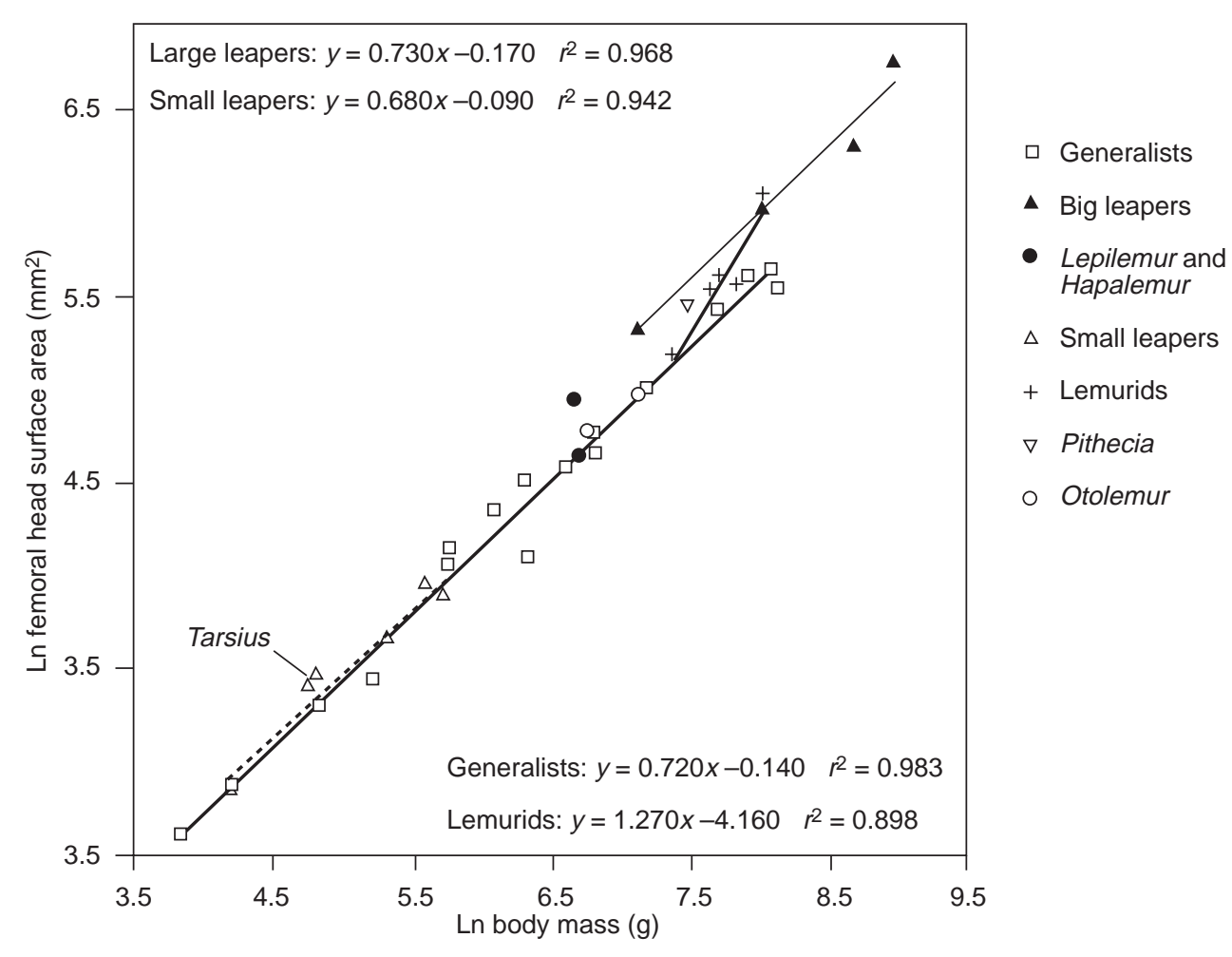

Fig. 7. Bivariate plot of femoral head surface area $v s$ body mass. The line-fitting technique is reduced major axis.

regressions from lemurids, generalists and atelines (Tables $4 \& 5$ ). Lemurids are significantly different from generalists (Table 6).

These differences, which largely reflect greater femoral rigidity in leapers relative to other groups, are clearly indicated in Fig. 4, humeral cortical area $v s$ femoral cortical area. All prosimian leapers fall to the femoral side of the generalist and ateline lines. Lemurids are positioned between large leapers and generalists. Pithecia does not group with other leapers, but instead, falls on the generalist line with the other platyrrhines. This is to be expected as Pithecia does not differ in relative femoral cortical area, but only relative femoral $J$, from generalists. Otolemur species are closer to the generalist regression than would be predicted from extrapolating the small leaper line upwards, reflecting their more quadrupedal behaviour relative to other galagos.

\section{Bone lengths}

As shown in Fig. 5, humeral length regressed on body mass, platyrrhine generalists have long humeri relative to similar-sized prosimians - leapers, lemurids, and prosimian generalists (Fig. 5, Tables 4 \& 6). The remaining platyrrhines, Pithecia and the atelines, are positioned above the prosimians in Fig. 5, as well. However, atelines are not significantly different from large leapers, perhaps because of the very low ateline correlation for this comparison. Among the prosimians, leapers, lemurids and prosimian generalists do not differ from each other in humeral length (Fig. 5, Tables 4-6). Otolemur species fall with both leaping and generalized prosimians.

Figure 6 shows femoral length regressed on body mass. Leapers clearly have much longer femora than do generalists (Table 4) and atelines (although atelines cannot be compared statistically as ateline femoral length on body mass does not correlate significantly). Leapers are also greater in relative femoral length than are lemurids (Fig. 6, Table 5). Lemurids, in turn, have relatively longer femora than do generalists (Fig. 6, Table 6). Among small leapers, tarsiers stand out in that their femora seems to be longer than those of galagonids. Pithecia has longer femora than most platyrrhines, and Otolemur species have shorter femora than do most leapers. Overall, femoral length increases with increasing leaping frequency, regardless of phylogenetic affinity.

Humeral length regressed on femoral length reflects patterns seen with humeral length and femoral length respectively regressed on body mass. Leapers differ strongly from both subgroups of generalists, and from lemurids and atelines (Tables $4 \& 5$ ). Lemurids differ in elevation from platyrrhines, but not from prosimian generalists.

\section{Articular surface areas}

Both strong leapers like indrids and intermediate leapers like lemurids have larger femoral heads than generalists 


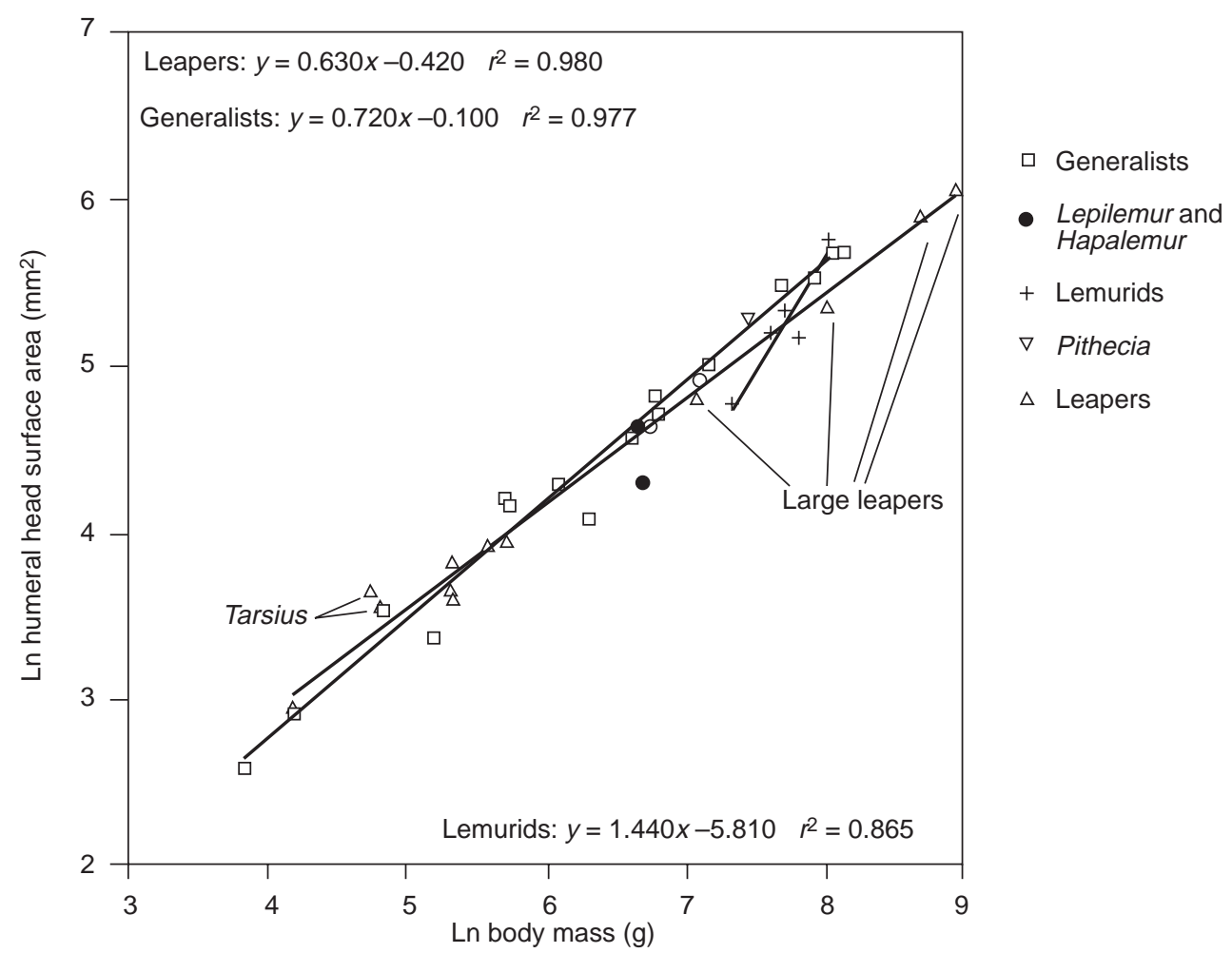

Fig. 8. Bivariate plot of humeral head surface area $v s$ body mass. The line-fitting technique is reduced major axis.

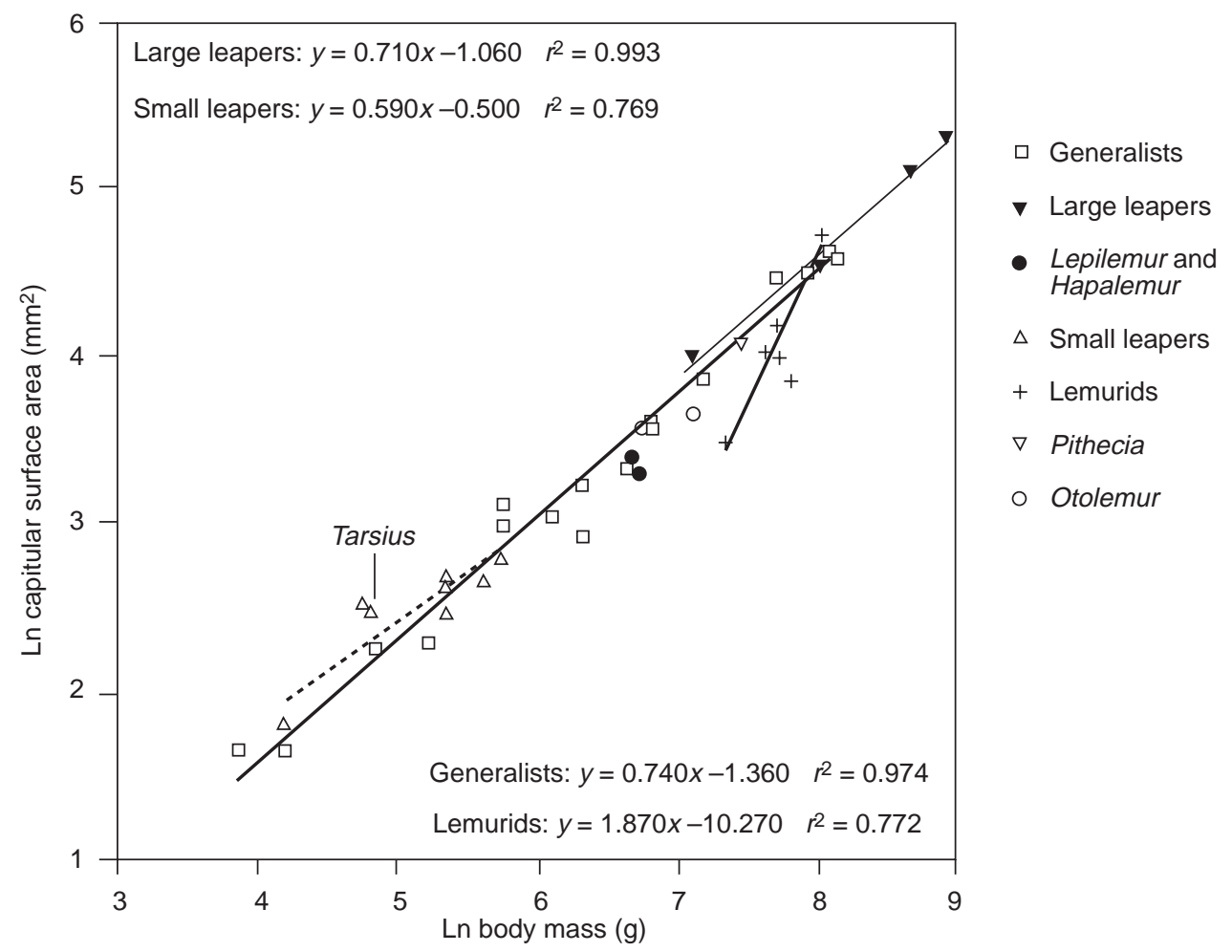

Fig. 9. Bivariate plot of humeral capitular surface area $v s$ body mass. The line-fitting technique is reduced major axis. 


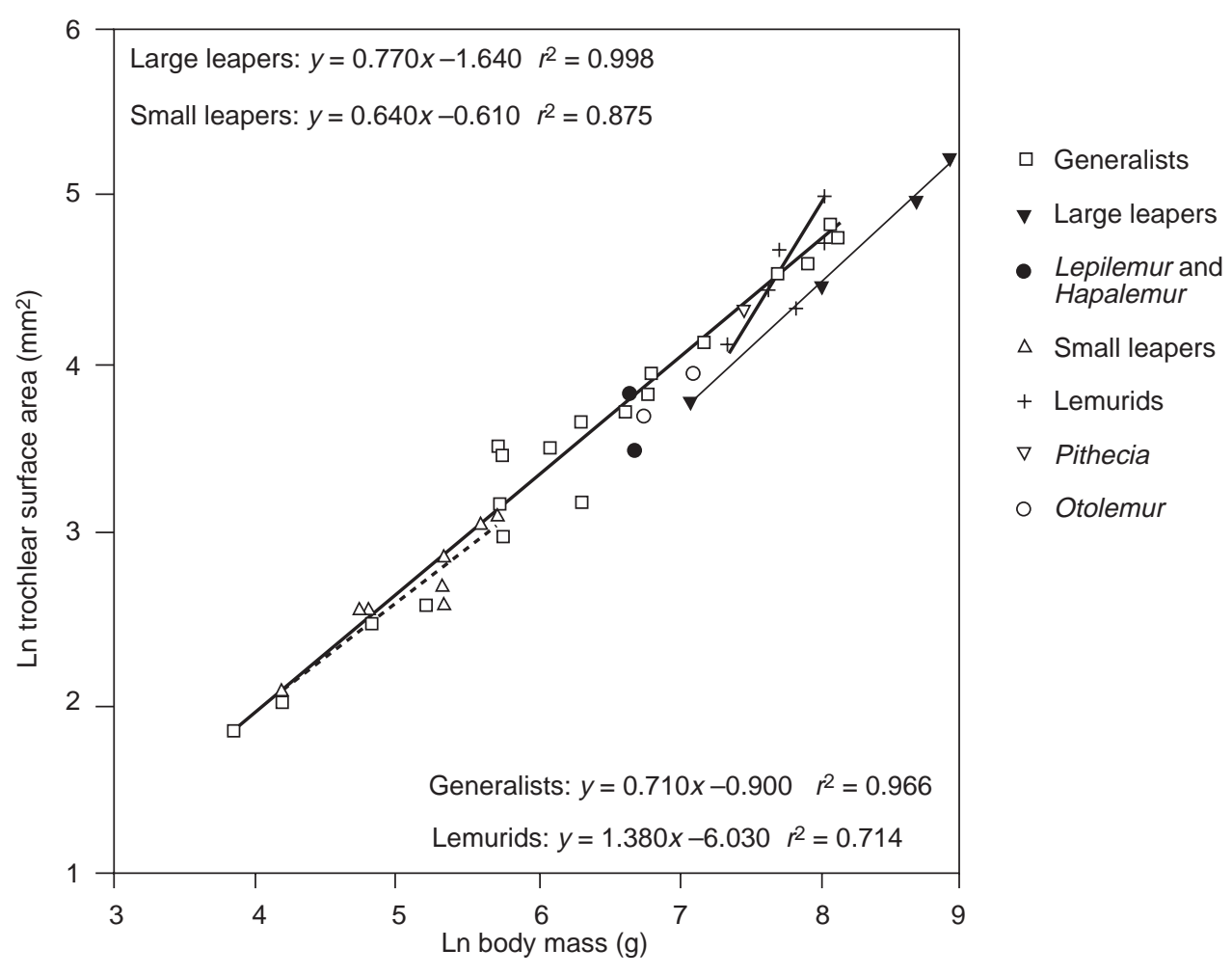

Fig. 10. Bivariate plot of humeral trochlear surface area $v s$ body mass. The line-fitting technique is reduced major axis.

or small leapers (Fig. 7, Tables 4 \& 5). Hapalemur and Pithecia, also, seem to have larger femoral heads than similar-sized generalists in Fig. 7. Lepilemur is the only lemur-like primate grouping with the generalists. Otolemur species also group with the small leapers and generalists. This is not surprising as most of the small leapers are galagos, such as Otolemur.

Humeral head surface area does not differ statistically in elevation between small and large leapers, nor between leapers and generalists (Tables $4 \& 5$ ). The only significant elevation difference is between generalists and lemurids - lemurids have slightly smaller humeral heads than do generalists (Table 6). However, as shown in Fig. 8, both lemurids and the large leapers are positioned below the generalist line. Apparently, both lemurs and indrids show a trend towards smaller humeral heads relative to other small primates.

Tarsiers may have both slightly larger humeral heads and slightly larger femoral heads than galagonids (Figs $7 \& 8$ ).

Humeral head surface area regressed on femoral head surface area largely reflects the effects of combining differences in relative femoral and humeral head sizes between the locomotory groups. Large leapers and lemurids are much different than generalists, and large leapers are slightly different than lemurids (Tables 4-6).

For the distal humerus, some interesting patterns appear. First of all, while there are no significant elevation differences between any of the groups for capitular surface area $v s$ body mass (Tables $4,5, \& 6$ ), Fig. 9, capitular surface area $v s$ body mass, does indicate a trend for most lemurids to have smaller capitula than similar-sized generalists. The capitula of large leapers do not appear to be smaller than those of generalists and other primates, and, in fact, may average slightly bigger (Fig. 9). Among the other leapers, tarsiers have relatively larger capitula than galagonids.

Trochlear surface area $v s$ body mass Fig. 10, yields a statistical difference indicating that large leapers have relatively smaller trochleae than do generalists and lemurids (Tables $4 \& 5$ ). Lemurids do not differ in elevation from generalists (Fig. 10, Table 6).

Many of the positional differences suggested by Figs $9 \& 10$ only reach statistical significance for the regression of capitular surface area on trochlear surface area, shown in Fig. 11. Large leapers differ from small leapers, generalists and lemurids (Tables 4 \& 5), and lemurids and generalists differ from each other (Table 6). For large leapers, this reflects relatively small trochleae, while for lemurids, this reflects relatively small capitula. Observe that Lepilemur and Hapalemur both fall close to the generalist line in Fig. 11 and are not similar to either of the other lemur-like groups.

\section{DISCUSSION}

\section{Leaper characteristics}

Features that small and large prosimian leapers have in common are relatively high femoral axial and torsional rigidity (femoral cortical area and $J$ ), greater femoral 


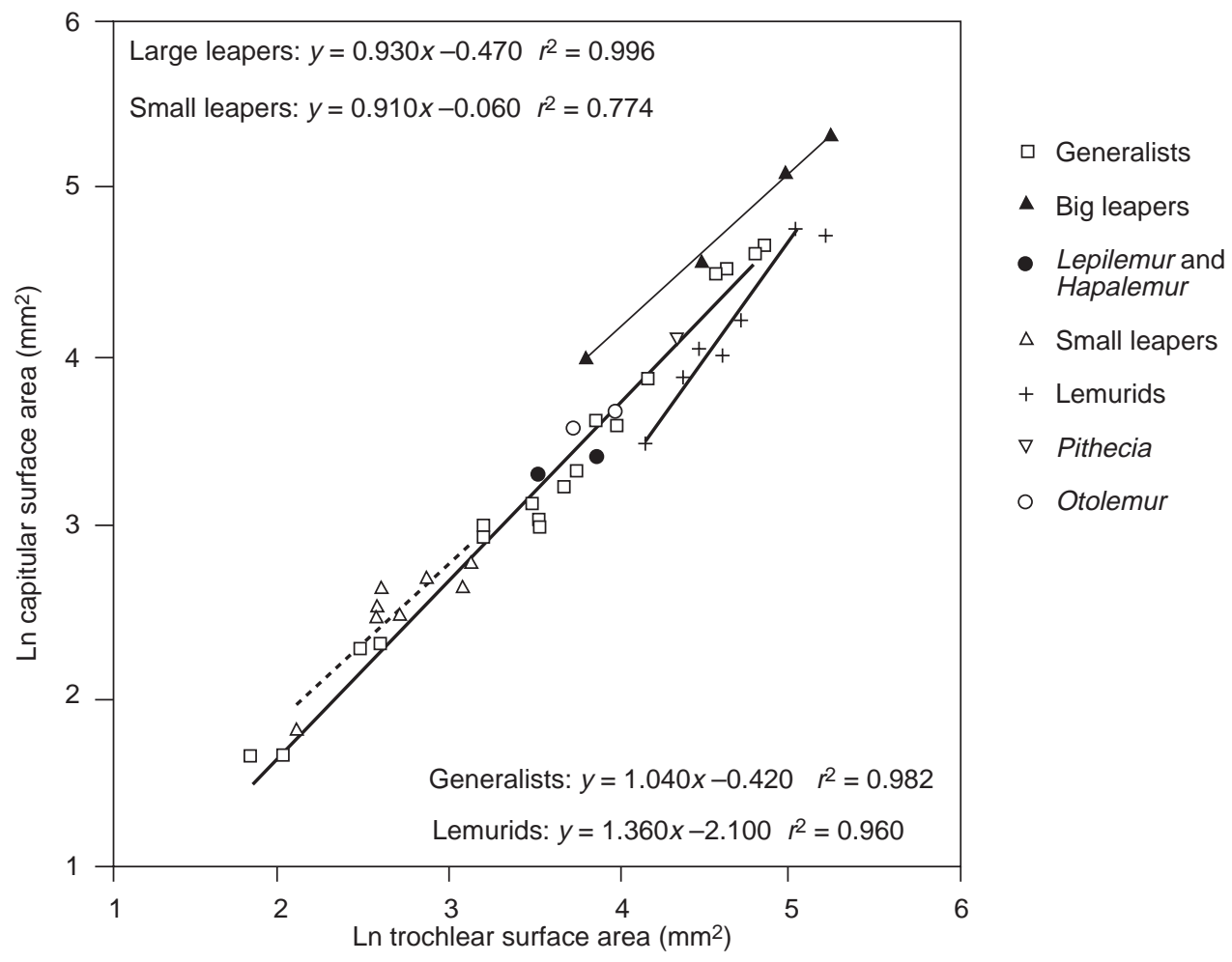

Fig. 11. Bivariate plot of humeral capitular surface area $v s$ trochlear surface area. The line-fitting technique is reduced major axis.

buttressing against loads applied in the sagittal plane relative to the coronal plane, slightly lower humeral buttressing against loads applied in the coronal plane relative to the sagittal plane, and long femora compared with more generalized primates.

Similar trends are seen among the secondary groups considered, supporting the assertion that leaping is functionally linked to high femoral rigidity and long femora. For example, the platyrrhine leaper Pithecia is like the prosimian leapers in having high femoral torsional rigidity and long femora, relative to generalists. Lemurids, which are intermediate in leaping frequency between large leapers and generalists, also plot between leapers and generalists in bivariate comparisons of femoral rigidity and length to body mass, although these differences are not always significant. Correspondingly, the quadrupedal galago species, Otolemur crassicaudatus and $O$. garnettii, have slightly reduced femoral rigidity and much shorter femora than leapers.

These results, which indicate that leaping causes femora to become more rigid, especially in the sagittal plane, and which suggest that leaping behaviour evolves together with increasing femoral length regardless of phylogenetic affinity or body size, are key findings from this study and corroborate well with results from previous studies. Greater femoral rigidity in leapers relative to more generalized primates was also found by Demes \& Jungers (1993) and Terranova (1995a). In these studies as well, the relative magnitudes of femoral cross-sectional properties often correspond with reported leaping frequency.

As limb bones increase in thickness and diameter in response to the loads applied (Lanyon \& Rubin, 1985), it is not surprising that the femora of leapers are more rigid than those of more generalized primates. The hindlimbs of leapers are used to propel them into the air and, at the end of leap trajectories, their hindlimbs often absorb the initial landing impact. Force plate data reported by Demes \& Günther (1989) indicate that Galago moholi, one of the species included in the present study, can exert forces over 12 times its body weight when launching into a leap (Demes \& Günther, 1989: fig.1). Estimates for tarsiers range up to 10 times body mass (Preuschoft, 1985: table 1). Data for larger leapers are also impressive with force pole results indicating peak launching forces of roughly 10 times body weight, and landing forces ranging around seven times body weight (Demes, Jungers, Gross et al., 1995: table 4).

Paine \& Godfrey's (1997) analysis of femoral microstructure yields further evidence for high stress levels in leaper hindlimbs. Comparing results for galagos to mostly quadrupedal Old World monkeys, they found unusually high densities of secondary osteons in Galago senegalensis femora. These osteons form in response to skeletal stresses.

The proportions of $I_{y}$ to $I_{x}$ seen in leaper and lemurid femora and humeri indicate that both bones have greater anteroposterior midshaft diameters than mediolateral ones, compared with generalist proportions. For 
the femur, this is because the AP plane $\left(I_{x}\right)$ is more buttressed relative to the ML plane $\left(I_{y}\right)^{2}$. In contrast, for the humerus, the proportions result from the ML diameter being relatively reduced in leapers.

Results by other workers also indicate that leaper femora are more buttressed in the AP plane, relative to the ML plane. Burr et al. (1982) demonstrated for galago femora that maximum $I$, the region of a crosssection with the most resistance to deformation, roughly corresponds to $I_{x}$, or the moment of inertia that passes through the AP plane. Burr et al. (1982) also demonstrated that the ML plane of the galago femur is relatively weak. In broader studies, relatively large AP dimensions were found for indrids by Demes, Jungers \& Selpien (1991), and for at least some galagos by Demes \& Jungers (1993) and Terranova $(1995 a, b)$ relative to lemurids.

With the exception of Daubentonia, these papers do not compare lemurids to more quadrupedal animals of similar body size. Results of the present study indicate that the femora of leapers and lemurids do not differ from each other in the proportion of AP to ML midshaft dimensions, and both groups differ from more generalized quadrupeds such as Chiropotes.

Greater femoral AP shaft dimensions in leapers and lemurids may reflect that in going from a crouched, vertically clinging position to a full leap take-off position, powerful hip and knee muscles are activated (Burr et al., 1982; Ruff \& Runestad, 1992). These muscles, the quadriceps and hamstrings, are predominantly aligned with the anterior and posterior surfaces of the femur, respectively. When they contract, the quadriceps pull anteriorly, while the hamstrings pull posteriorly on the femur, probably causing bone to be laid down on both sides. Of course, this assumes that muscles originating on the pelvis are not strongly angled so as to create large mediolateral forces (Ruff, 1989; Ruff \& Runestad, 1992).

Humeral data from different studies also show agreement in that no differences between leaping taxa and lemurids in proportions of humeral $I_{y}$ to $I_{x}$ are indicated (Demes \& Jungers, 1993; Terranova, 1995a). However, these studies compare leapers to few of the present study's generalists, and, therefore, miss the difference between leapers and generalists seen in this study.

Lower humeral ML shaft dimensions in leapers and lemurids or greater ML shaft dimensions in generalists, may reflect loading placed on the mid-humerus by insertions for muscles such as the pectoralis group and the latissimus dorsi. The pectoral muscles function to pull the forelimb forward from an extended position (in the anatomical sense), and both the pectoral muscles and the latissimus dorsi function to extend the forelimb from a flexed position (pull it backwards). Both of these movements are important in quadrupedal running and walking such as that displayed by generalists. Therefore, the muscles involved may be more powerfully developed

\footnotetext{
${ }^{2}$ Note that leapers are probably greater in both femoral $I_{x}$ and $I_{y}$ relative to body mass than are generalists; it is the proportion of $I_{x}$ to $I_{y}$ that is under discussion.
}

than in leapers. Both muscles, additionally, function to pull the limb closer to the body when the arm is abducted. This is especially important because, as described by Fleagle (1988), arboreal quadrupeds habitually walk on tree branches with their limbs slightly abducted. Combined with slight elbow flexion, this serves to bring the body's centre closer to the branch and, thus, to reduce the chances of falling (Fleagle, 1988).

Relatively long leaper femora are reported from numerous sources (A. C. Walker, 1974; Jouffroy \& Lessertisseur, 1979; Jungers, 1979; Anemone, 1990). Long femora provide an advantage by increasing the duration of push-off from substrates at the start of a leap (Demes \& Günther, 1989; Preuschoft, 1990). Longer push-offs increase the time available to exert force against a support, resulting in more momentum as the leap begins.

\section{Differences between small and large leapers}

Almost all of the leapers above a certain size - indrids, Hapalemur and Pithecia - have relatively large femoral heads. This is true to a lesser extent for the lemurids which are intermediate in leaping frequency between most leapers and generalists. Small leapers - galagos and tarsiers - do not have femoral heads any larger than would be expected for generalist primates of similar body size.

Godfrey et al. (1995) found that indrids, lemurids and Lepilemur have large femoral heads relative to humeral heads compared with more generalized primates Their analysis does not compare femoral head size directly with body mass, nor do they have enough small leapers in their sample to be able to recognize a consistent difference related to body size.

However, Godfrey et al. (1995) additionally show that the ratio of femoral head to humeral head size is large in many climbing specialized animals, some of whom are close relatives of indrids and lemurids, and Runestad (1997) reports that large femoral heads relative to body mass are also seen in slow-climbing lorids. The presence of large femoral heads in both bigger leapers (prosimians and Pithecia) and climbing specialists suggests similar mobility needs at the hip joint, as large ranges of hip motion have been observed for both lorids (Subramoniam, 1957) and indrids (Demes, Jungers, Fleagle et al., 1996).

The cylindrical shape of galago and tarsier femoral heads suggests reduced mobility as cylindrical joints are most commonly found in articulations stressing flexionextension at the expense of other movements (Currey, 1984). However, the femoral heads of both large and small leapers must be able to transmit large forces as indicated by their high femoral diaphyseal rigidity and laboratory force plate data (Alexander, 1980; Demes \& Günther, 1989; Demes, Jungers, Gross et al., 1995). Small leapers do have denser femoral heads than either generalists or large leapers (Egi, Ruff \& Runestad, 
1995), which may be a way of compensating for not increasing total articular area. Large leapers have femoral head density levels that are comparable to those of generalized primates, while their external surface areas are larger. Presumably, their greater femoral head size distributes forces over a greater area, reducing the need for increased bone density. However, Godfrey et al. (1995) warn that the ability of a joint to withstand stress is limited by which joint surface is smaller, and limited data in Runestad (1994) suggest that indrids may have small acetabula.

\section{Lemur-like primate characteristics}

Features shared by indrids and lemurids include low humeral diaphyseal axial rigidity (humeral cortical area), small humeral heads, and large femoral heads. Relatively big femoral heads are also seen in other large leapers, such as Pithecia, as discussed above.

Reduced humeral rigidity make sense for the indrids (large leapers), as they have very low frequencies of quadrupedal running or walking (Gebo, 1987; Dagosto, 1995). In addition, they usually first strike landing supports with their hindlimbs during leaps (Demes, Jungers, Fleagle et al., 1996), unlike many of the smaller leapers which often use their forelimbs (Oxnard et al., 1990; Terranova, 1995b).

Some indrid species frequently use their forelimbs for suspensory behaviour (Vasey, 1992). However, this mostly occurs during low-impact feeding (grabbing leaves) (Vasey, 1992), and at much lower frequencies than in many generalized primates (Gebo, 1987).

The lower humeral axial rigidity of lemurids is difficult to explain. While lemurids are not as quadrupedal as similar-sized generalists such as Daubentonia and Cebus monkeys, they are probably more quadrupedal than most of the small leapers that have humeral cortical area levels comparable to generalists (see Fig. 3). Also, Hapalemur and Pithecia are not low in humeral cortical area, and both are accomplished leapers (see Introduction and Materials).

Because low humeral cortical area is a trait lemurids share with indrids, perhaps common muscle arrangements function to reduce axial loads in the forelimb. Both the absence of this trait and the presence of 'normal-sized' humeral heads in cheirogaleids, which may be more closely related to lemurids than indrids are (Yoder et al., 1996), suggest that these proportions were present in the hypothetical ancestor of all three families, but were changed in cheirogaleids. Alternatively, the humeral proportions lend further support to trees that place indrids and lemurids close together to the exclusion of cheirogaleids (Yoder et al., 1996; Yoder, 1997).

\section{Features unique to indrids}

Indrids are unique in that they are the only group in the study to have reduced humeral trochleae. Their capitula do not appear to differ from the proportions seen in generalized primates.

Szalay \& Dagosto (1980) observed that the trochleae of indrids are high and narrow relative to other small primates. The reduced width probably contributes to the overall small size of the joint observed in the present study. The apparently enhanced height of the joint (Szalay \& Dagosto, 1980) suggests an adaptation for extremely flexed elbows used for clinging vertically to arboreal supports.

\section{Features unique to lemurids}

Most lemurids differ from the other primates in the study, including indrids, in having smaller capitula, while their trochleae do not appear to differ from those of generalists. It is not readily apparent what the advantage of reducing the capitulum would be for an arboreal primate, as one would expect this to restrict elbow rotation. Perhaps this trait is simply a primitive retention.

The largest lemurid, Varecia, is also the most unusual morphologically. Unlike the other lemurs, Varecia does not have a relatively small humeral head area, relatively low humeral cortical area, or a relative small capitular area. Varecia does have longer humeri than other prosimians, and its femoral head surface area and femoral diaphyseal rigidity are as large as those of indrids.

Many of these features tie in well with the greater frequency of suspensory behaviour seen in Varecia relative to the other lemurids (Gebo, 1986; Pereira et al., 1988; Dagosto, 1995). Large articulations at rotational joints (humeral and femoral heads and humeral capitulum), high diaphyseal rigidity, and long humeri are features also seen in highly suspensory lorids relative to more generalized primates (Runestad, 1997).

\section{Differences among small leapers}

The subgroup small leapers contains both tarsiers and galagonids, two groups that probably diverged before the Eocene (Martin, 1994). Unfortunately, because there are only two tarsier species, it was not possible to compare them statistically to the galagos before lumping the two families together. The only ways of checking for phylogenetic differences are to examine nesting effects from calculation of effective $n$ values and to look at bivariate plots.

Comparisons of observed $n$ and effective $n$ values in Table 2 indicate sharp differences within small leapers for femoral head surface area regressed on body mass, and for capitular surface area regressed on body mass. For the bivariate comparisons where small leapers are combined with large leapers, the leapers show the most marked differences between observed and effective $n$ values for femoral length $v s$ body mass, and for humeral 
head surface area $v s$ body mass (Table 2). Nesting effects are significant at the family level for these last two comparisons $(\alpha<0.05)$.

While some of this phylogenetic linkage can be traced to the inclusion of indrids in the overall leaper sample, the corresponding bivariate plots strongly suggest that the inclusion of tarsiers is partly responsible. Tarsiers, the second and third smallest leapers, are positioned above the regression line for femoral length $v s$ body mass (Fig. 6), indicating relatively longer femora than in the other small leapers. Tarsiers also appear to have slightly larger femoral and humeral heads (Figs $7 \&$ 8), and much larger capitula (Fig. 9) than galagos.

These differences correspond to observations made by others. Jouffroy, Berge \& Niemitz (1984) also found that tarsiers have longer femora than do galagos. Additionally, Jouffroy, Oxnard \& German (1982) noticed differences between tarsiers and galagos in their multivariate analysis of small leaper limb proportions.

Although behavioural comparisons are not available, tarsiers may be more saltatory than galagos. While both groups can progress quadrupedally, for tarsiers this behaviour is usually restricted to climbing through dense brush, not moving along the ground (MacKinnon \& MacKinnon, 1980; Crompton \& Andau, 1986) Tarsiers also land hind-feet first consistently (Crompton \& Andau, 1986). However, as indicated by Oxnard et al. (1990), different sources sometimes conflict. Tarsiers may also be better at climbing and suspending than galagos, as suggested by the larger size of tarsier humeral and femoral heads and capitula. Despite the absence of direct behavioural comparisons, therefore, it is reasonable to hypothesize that tarsiers may be more frequent climbers or suspensionists than galagos.

\section{Atelines}

This paper does not attempt a thorough analysis of the relationship between skeletal morphology and locomotory behaviour in atelines. Also, no articular data are available for atelines. None the less, some trends can be observed.

First, atelines as a group are similar in cross-sectional properties to the smaller platyrrhines. The only significant difference is a slight one in proportions of humeral cortical area to humeral J. A bivariate plot of humeral $J v s$ body mass (not shown) indicates that this is a result of non-significantly greater torsional rigidity in atelines.

Second, the bivariate plots show that most atelines are positioned well above extrapolations of the generalists in humeral length, and slightly below generalists in femoral length, except for Ateles (see Figs 5 \& 6). These differences are not significant, but this is probably because of very low ateline correlations.

The ateline data described matches behavioural information which indicates more frequent use of the forelimbs during travel than in the generalist platyr- rhines. Both Alouatta and Ateles have lower percentages of leaping and higher percentages of suspensory behaviour than Saimiri, Cebus or Chiropotes (Fleagle \& Mittermeier, 1980; Fontaine, 1990; Bergeson, 1996). This may be the cause of the slightly greater ateline humeral torsional rigidity, longer humeri, and slightly shorter femora.

The Ateles species data points stand out from the other atelines in many of the bivariate comparisons. Ateles have longer humeri and femora than do the other atelines (Figs $5 \&$ 6), and greater femoral rigidity (Figs $1 \& 2$ ). They approach the leapers in femoral rigidity and length.

The overall greater limb length in Ateles may be related to their more frequent use of suspensory behaviours involving different combinations of forelimb, hindlimb and tail use (Bergeson, 1996). In addition, Ateles are reported to engage in occasional bipedal walking (Fontaine, 1990; Bergeson, 1996). In combination with frequent hindlimb suspension, this behaviour would theoretically stress the hindlimbs more than quadrupedal progression, thus, resulting in greater femoral rigidity.

\section{Allometric patterns}

The positive allometry seen in leapers and generalists in diaphyseal cross-sectional properties matches well with theoretical expectations. If animals increased in body mass (or volume) with geometric similarity, then their area dimensions would increase only to the two-thirds power of body mass. This means that larger animals would have less diaphyseal cross-sectional area of the limb bones to support more body mass. Therefore, one would not expect larger animals to be geometrically similar to smaller animals, but, rather, to show positive allometry in limb bone cross-sectional area.

The slopes for the small samples (lemurids and atelines) may not be meaningful for identifying scaling patterns. The lemurid lines connect three data points, with Varecia and Eulemur coronatus at the extremes, and the remaining four lemur species clump together to form a middle data point. The positions of Varecia and E. coronatus strongly influence the slope, while the positions of the other four lemurs individually have little impact. While the ateline data are not clumped, they do not have very strong correlations. Ateline data often resemble a cluster more than a regression - see Figs 1-6.

Contributing to these patterns, both lemurid and ateline slopes have one notable problem: the biggest species are behaviourally different than the others. The first and third largest atelines are highly suspensory Ateles species. The largest lemurid is Varecia which is more suspensory than the other lemurids. The presence of these species at the high end of the regressions cannot but help to raise the slopes of cross-sectional properties, bone lengths, and articular dimensions beyond that expected from scaling effects alone. 


\section{CONCLUSIONS}

Leaping-specialized primates are characterized by high femoral diaphyseal rigidity (especially in the anteroposterior plane), slightly reduced humeral mediolateral rigidity, and long femora compared to other primates of similar body size. The enhanced femoral rigidity is interpreted as a response to high forces incurred during leaping. Long femoral length is viewed as an adaptation to increase the efficiency and duration of leaps. Prosimians with slightly lower leaping frequencies are intermediate in many of these features between the leapers and more generalized primates. Pithecia, a nonprosimian leaper, also displays many of these leaper characteristics.

Large-bodied indrid leapers differ from small-bodied leapers such as galagonids and tarsiers in having large femoral heads. Large femoral head surface area is also seen in Hapalemur, Pithecia and, to a lesser extent, in lemurids. This feature is probably linked to leaping in larger animals - perhaps these animals have more mobile hip joints, while the hips of the smaller leapers are more restricted. Larger femoral heads may also allow for greater force transmission, although this explanation does not address the reduced acetabular size seen in some indrids. Data from another study suggest that small leaper femoral heads are denser internally, possibly compensating for less area for force transmission through the hip joint.

In addition to large femoral heads, features characteristic of lemur-like primates include relatively small humeral heads and reduced humeral diaphyseal cortical area. These features may be primitive characteristics retained from a common ancestor. The low humeral cortical area may result from similar muscle arrangements. Functional explanations related to reduced quadrupedalism are also explored.

Several primate taxa show unique morphological patterns. Indrids are characterized by reduced humeral trochlear surface area. This probably reflects their low frequency of pronograde locomotion. Lemurids show a trend for reduced humeral capitular area, a trait that does not appear to confer any adaptive advantage, but which may be a primitive trait. Among the atelines, Ateles species have longer humeri and femora, and greater femoral diaphyseal rigidity. These features are probably linked to their greater frequency of suspensory behaviour, relative to other atelines.

Several femoral features are seen in leapers of diverse phylogenetic histories. These characteristics are useful for interpretation of locomotory behaviour in fossil primates where taxonomic links to living forms are not well understood. In addition, large femoral head size is common in leapers above a certain body size. Other features may be strongly tied to ancestral morphology, such as humeral articular morphology, and may not be as useful for functional interpretation of fossil material. Overall, analysis of leaper postcrania reveals a mix of features, some of which can be easily interpreted from a functional perspective, while others hint at retention of primitive patterns.

\section{Acknowledgements}

The authors are grateful for the assistance of many people during data collection and manuscript preparation. We thank: Dr C. B. Ruff and Dr K. D. Rose, advisors, as well as their fellow committee members Dr D. L. Gebo, Dr W. L. Jungers, and Dr R. W. Thorington, Jr. for comments on the dissertation of J. A. Runestad Connour from which this paper is partially derived; Dr Ruff, in particular, provided considerable assistance; Dr S. K. Bearder, Dr D. Bergeson, Dr M. Cartmill, Dr M. Dagosto, Dr L. C. Davis; Dr B. Demes, Dr N. Egi, Dr L. R. Godfrey, Dr W. L. Jungers, Dr R. F. Kay, E. C. Kirk, Dr S. Larson, Professor Dr R. D. Martin, Dr T. Olson, Professor Dr H. Preuschoft, Dr K. L. Rafferty, Dr E. Sterling, Dr M. F. Teaford, Dr C. Terranova, Dr N. Vasey, Dr A. Walker, Dr S. Walker, Dr B. A. Williams and Dr A. Yoder for access to dissertations, literature, and/or field data; Dr G. Dieringer and A. van Nievalt for assistance with statistics; and Dr M. Godinot for assistance with making arrangements. The authors also thank the editorial staff of the journal and two anonymous reviewers whose suggestions greatly improved this paper. Sincere apologies are made to colleagues whose work is not cited in this paper, specifically, many excellent sources on locomotory behaviour. Priority was given to field studies, newer sources, broader studies and completed published works. Data collection for this paper involved numerous visits to museums with concomitant need for radiographing and lodging arrangements. We thank: Dr R. MacPhee, Dr G. Musser, Dr A. R. Biknevicius, W. Fuchs, B. Mader, M. N. Feinberg and staff at the American Museum of Natural History; Professor Dr R. Martin, Dr U. Thalmann and associates at the Anthropologisches Institut and Museum of the Universität Zürich-Irchel, Switzerland; Dr J. Mercer at the Duke University Department of Zoology; P. D. Jenkins and staff at the Natural History Museum, London; Dr L. Heaney, Dr B. Patterson, Dr M. A. Rogers, Dr W. Stanley, Dr M. Solomon, K. Swagel and staff at the Field Museum of Natural History, Chicago; Dr M. Rutzmoser, Dr A. W. Crompton, Dr F. Jenkins and their respective staffs at the Harvard Museum of Comparative Zoology, Professor Repeyrand, Dr Tranier, Dr L. Ginsburg, Dr P. Taquet, J. Cuisin and associates at the Muséum National d'Histoire Naturelle, Paris; Dr C. Smeenk, Professor Dr J. L. Dubbeldam and their respective associates and staffs at the Rijksmuseum van Natuurlijke Historie in Leiden, The Netherlands; Dr E. Déan and Dr N. Verrière at the University of Paris X, Nanterre; also, Dr M. Cantini for his assistance in Paris; Dr R. W. Thorington, Jr., L. Gordon, L. Coley and J. Jacobs at the U.S. National Museum of Natural History, Smithsonian Institution. Debts of hospitality 
are owed to the Thalmann family of Zurich, the Seidel family of Bad Neuenahr-Ahrweiler, Germany, and the Davies family of Llantwitt Major, Wales. Funding was provided through National Science Foundation Dissertation Improvement Grant BNS9120164, an American Museum of Natural History Collection Study Grant, and a Western Illinois University Research Council Grant.

\section{REFERENCES}

Alexander, R. M. (1980). Forces in animal joints. Engineering Med. 9: 93-97.

Anemone, R. L. (1990). The VCL hypothesis revisited: patterns of femoral morphology among quadrupedal and saltatorial prosimian primates. Am. J. Phys. Anthropol. 83: 373-393.

Beard, K. C., Qi, T., Dawson, M. R., Wang, B. \& Li, C. (1994). A diverse new primate fauna from middle Eocene fissure-fillings in southeastern China. Nature (Lond.) 368: 604-609.

Bearder, S. K. (1987). Lorises, bushbabies, and tarsiers: diverse societies in solitary foragers. In Primate Societies: 11-43. Smuts, B. B., Cheney, D. L., Seyfarth, R. M., Wrangham, R. W. \& Struhsaker, T. T. (Eds). Chicago: University of Chicago Press.

Bearder, S. K. \& Doyle, G. A. (1974). Ecology of bushbabies Galago senegalensis and Galago crassicaudatus, with some notes on their behavior in the field. In Prosimian Biology: 109-130. Martin, R. D., Doyle, G. A. \& Walker, A. C. (Eds). Pittsburgh: University of Pittsburgh Press.

Bergeson, D. (1996). The positional behavior and prehensile tail use of Alouatta palliata, Ateles geoffroyi, and Cebus capucinus. $\mathrm{PhD}$ dissertation, Washington University (St Louis).

Biknevicius, A. R. \& Ruff, C. B. (1992). Use of biplanar radiographs for estimating cross-sectional geometric properties of mandibles. Anat. Rec. 232: 157-163.

Burr, D. B., Piotrowski, G., Martin, R. B. \& Cook, P. N. (1982). Femoral mechanics in the lesser bushbaby (Galago senegalensis): structural adaptations to leaping in primates. Anat. Rec. 202: 419-429.

Charles-Dominique, P. (1977). Ecology and behavior of nocturnal primates. New York: Columbia University Press.

Charles-Dominique, P. \& Bearder, S. K. (1979). Field studies of lorisid behavior: methodological aspects. In The study of prosimian behavior: 567-629. Doyle, G. A. \& Martin, R. D. (Eds). New York: Academic Press.

Charles-Dominique, P. \& Martin, R. D. (1972). Behaviour and ecology of nocturnal prosimians/comportement et ecologie de prosimiens nocturnes. Berlin: Paul Parey.

Charles-Dominique, P. \& Petter, J.-J. (1980). Ecology and social life of Phaner furcifer. In Nocturnal Malagasy primates: 75-95. Charles-Dominique, P., Cooper, H. M., Hladik, A., Hladik, C. M., Pages, E., Pariente, G. F., Rousseaux-Petter, A., Petter, J. J. \& Schilling, A. (Eds). New York: Academic Press.

Christen, A. (1974). Fortpflanzungsbiologie und Verhalten bei Cebuella pygmaea und Tamarin tamarin (Primates, Platyrrhina, Callithricidae). Berlin: Paul Parey.

Crompton, R. H. (1984). Foraging, habitat structure, and locomotion in two species of Galago. In Adaptations for foraging in nonhuman Primates: 73-111. Rodman, P. S. \& Cant, J. G. H. (Eds). New York: Columbia University Press.

Crompton, R. H. \& Andau, P. M. (1986). Locomotion and habitat utilization in free-ranging Tarsius bancanus: a preliminary report. Primates 27: 337-355.

Currey, J. (1984). The mechanical adaptations of bone. Princeton: Princeton University Press.
Currey, J. D. (1968). The adaptation of bones to stress. J. theor. Biol. 20: 91-106.

Dagosto, M. (1985). The distal tibia of primates with special reference to the Omomyidae. Int. J. Primatol. 6: 45-75.

Dagosto, M. (1988). Implications of postcranial evidence for the origin of euprimates. J. Hum. Evol. 17: 35-56.

Dagosto, M. (1994). Testing positional behavior of Malagasy lemurs: a randomization approach. Am. J. Phys. Anthropol. 94: 189-202.

Dagosto, M. (1995). Seasonal variation in positional behavior of Malagasy lemurs. Int. J. Primatol. 16: 807-833.

Dagosto, M. \& Schmid, P. (1996) Proximal femoral anatomy of omomyiform primates. J. Hum. Evol. 30:29-56

Demes, B. \& Günther, M. M. (1989). Biomechanics and allometric scaling in primate locomotion and morphology. Folia Primatol. 53: $125-141$.

Demes, B. \& Jungers, W. L. (1993). Long bone cross-sectional dimensions, locomotor adaptations and body size in prosimian primates. J. Hum. Evol. 25: 57-74.

Demes B., Jungers, W. L., Fleagle J. G., Wunderlich R. E., Richmond B. G. \& Lemelin, P. (1996). Body size and leaping kinematics in Malagasy vertical clingers and leapers. J. Hum. Evol. 31: 367-388.

Demes, B., Jungers, W. L., Gross, T. S. \& Fleagle, J. G. (1995). Kinetics of leaping primates: influence of substrate orientation and compliance. Am. J. Phys. Anthropol. 96: 419-429.

Demes, B., Jungers, W. L. \& Selpien, K. (1991). Body size, locomotion, and long bone cross-sectional geometry in indriid primates. Am. J. Phys. Anthropol. 86: 537-547.

Dutrillaux, B. \& Rumpler, Y. (1995). Phylogenetic relations among Prosimii with special reference to Lemuriformes and Malagasy nocturnals. In Creatures of the dark: the nocturnal prosimians: 141-150. Alterman, L., Doyle, G. A. \& Izard, M. K. (Eds). New York: Plenum Press.

Egi, N., Ruff, C. B. \& Runestad, J. A. (1995). Structural adaptations for leaping in the proximal femur of VCL prosimians. Am. J. Phys. Anthropol. Suppl. 20: 87-88.

Fleagle, J. G. (1988). Primate adaptation and evolution. San Diego: Academic Press.

Fleagle, J. G. \& Mittermeier, R. A. (1980). Locomotor behavior, body size, and comparative ecology of seven Surinam monkeys. Am. J. Phys. Anthropol. 52: 301-314.

Fleagle, J. G. \& Simons, E. L. (1983). The tibio-fibular articulation in Apidium phiomense, an Oligocene anthropoid. Nature (Lond.) 301: 238-239.

Fogden, M. P. L. (1974). A preliminary field study of the western tarsier, Tarsius bancanus Horsfield. In Prosimian biology: 141165. Martin, R.D., Doyle, G. A. \& Walker, A. C. (Eds). Pittsburgh: University of Pittsburgh Press.

Fontaine, R. (1990). Positional behavior in Saimiri boliviensis and Ateles geoffroyi. Am. J. Phys. Anthropol. 82: 485-508.

Ford, S. M. \& Davis, L. C. (1992). Systematics and body size: implications for feeding adaptations in New World monkeys. Am. J. Phys. Anthropol. 88: 415-468.

Garber, P. A. (1991). A comparative study of positional behavior in three species of tamarin monkeys. Primates 32: 219-230.

Gebo, D. L. (1986). The anatomy of the prosimian foot and its application to the primate fossil record. $\mathrm{PhD}$ thesis, Duke University, Durham, North Carolina.

Gebo, D. L. (1987). Locomotor diversity in prosimian primates. Am. J. Primatol. 13: 271-281.

Glander, K. E., Wright, P. C., Daniels, P. S. \& Merenlender, A. M. (1992). Morphometrics and testicle size of rain forest lemur species from southeastern Madagascar. J. Hum. Evol. 22: $1-17$.

Godfrey, L. R., Sutherland, M. R., Paine, R. R., Williams, F. L., Boy, D. S. \& Vuillaume-Randriamanantena, M. (1995). Limb joint surface areas and their ratios in Malagasy lemurs and other mammals. Am. J. Phys. Anthropol. 97: 11-36. 
Harcourt, C. S. (1984). The behaviour and ecology of galagos in Kenyan coastal forest. $\mathrm{PhD}$ thesis, University of Cambridge, Cambridge.

Harcourt, C. S. \& Bearder, S. K. (1989). A comparison of Galago moholi in South Africa with Galago zanzibaricus in Kenya. Int J. Primatol. 10: $35-45$.

Hladik, C. M., Charles-Dominique, P. \& Petter, J.-J. (1980). Feeding strategies of five nocturnal prosimians in the dry forest of the west coast of Madagascar. In Nocturnal Malagasy primates: 41-73. Charles-Dominique, P., Cooper, H. M., Hladik, A., Hladik, C. M., Pages, E., Pariente, G. F., RousseauxPetter, A., Petter, J. J. \& Schilling, A.. (Eds). New York: Academic Press.

Hofman, M. A. (1988). Allometric scaling in palaeontology: a critical study. Hum. Evol. 3: 177-188.

Jouffroy, F. K. \& Lessertisseur, J. (1979). Relationships between limb morphology and locomotor adaptations among prosimians: an osteometric study. In Environment, behavior, and morphology: dynamic interactions in primates: 143-181. Morbeck, M. E., Preuschoft, H. \& Gomberg, N. (Eds). New York: Gustav-Fischer.

Jouffroy, F. K., Berge, C. \& Niemitz, C. (1984). Comparative study of the lower extremity in the genus Tarsius. In Biology of tarsiers: 167-190. Niemitz, C. (Ed.). Stuttgart: Gustav Fischer Verlag.

Jouffroy, F. K., Oxnard, C. E. \& German, R. (1982). Interprétation phylogénétique des proportions des membres des tarsiers. Analyse discriminante. C. R. Acad. Sc. Paris 295: 315-320.

Jungers, W. L. (1979). Locomotion, limb proportions, and skeletal allometry in lemurs and lorises. Folia Primatol. 32: 8-28.

Jungers, W. \& Burr, D. (1994). Body size, long bone geometry and locomotion in quadrupedal monkeys. Z. Morphol. Anthropol. 80: 89-97.

Kappeler, P. M. (1991). Patterns of sexual dimorphism in body weight among prosimian primates. Folia Primatol. 57: 132-146.

Lanyon, L. E. \& Rubin, C. T. (1985). Functional adaptation in skeletal structures. In Functional vertebrate morphology: 1-25. Hildebrand, M., Bramble, D. M., Liem, K. F. \& Wake, D. B. (Eds). Cambridge: Belknap Press.

MacKinnon, J. \& MacKinnon, K. (1980). The behavior of wild spectral tarsiers. Int. J. Primatol. 1: 361-379.

MacLarnon, A. M. (1989). Applications of the Reflex instruments in quantitative morphology. Folia Primatol. 53: 33-49.

Martin, R. D. (1994). Bonanza at Shanghuang. Nature (Lond.) 368: $586-587$.

Masters, J. C. (1985). Species within the axon Galago crassicaudatus E. Geoffroy. PhD thesis, University of the Witwatersrand, Johannesburg.

Napier, J. R. \& Walker, A. C. (1967). Vertical clinging and leaping - a newly recognized category of locomotor behaviour of primates. Folia Primatol. 6: 204-219.

Nash, L. T. \& Harcourt, C. S. (1986). Social organization galagos in Kenyan coastal forests: II. Galago garnettii. Am. J. Primatol. 10: $357-369$.

Nash, L. T., Bearder, S. K. \& Olson, T. R. (1989). Synopsis of Galago species characteristics. Int. J. Primatol. 10: 57-80.

Niemitz, C. (1979). Outline of the behavior of Tarsius bancanus. In The study of prosimian behavior: 631-660. Doyle, G. A. \& Martin, R. D. (Eds). New York: Academic Press.

Oxnard, C. E. (1981). The uniqueness of Daubentonia. Am. J. Phys. Anthropol. 54: 1-21.

Oxnard, C. E., Crompton, R. H. \& Liebermann, S. S. Animal lifestyles and anatomies: the case of the prosimian primates. Seattle: University of Washington Press.

Paine, R. R. \& Godfrey, L. R. (1997). The scaling of skeletal microanatomy in non-human primattes. J. Zool. (Lond.) 241: 803-821.

Pereira, M. E., Selligson, M. L. \& Macedonia, J. M. (1988). The behavioral repertoire of the black-and-white ruffed lemur,
Varecia variegata variegata (Primates: Lemuridae). Folia Primatol. 51: 1-32.

Petter, J.-J. (1962). Recherches sur l'écologie et l'éthologie des lemuriens Malgaches. Paris: Éditions du Muséum.

Petter, J. \& Peyrieras, A. (1970a). Nouvelle contribution a l'etude d'un lemurien Malgache, le aye-aye (Daubentonia madagascariensis E. Geoffroy). Mammalia 34: 167-193.

Petter, J.-J. \& Peyrieras, A. (1970b). Observations éco-éthologiques sur les lemuriens Malgaches du genre Hapalemur. Terre Vie 24: 356-382.

Petter, J.-J. \& Peyrieras, A. (1975). Preliminary notes on the behavior and ecology of Hapalemur griseus. In Lemur biology: 281-286. Tattersall, I. \& Sussman, R. W. (Eds). New York: Plenum Press.

Petter, J.-J., Schilling, A. \& Pariente, G. (1971). Observations éco-éthologiques sur deux lemuriens Malgaches nocturnes: Phaner furcifer et Microcebus coquereli. Terre Vie 3: 287-327.

Pollock, J. I. (1975). Field observations on Indri indri: a preliminary report. In Lemur biology: 287-311. Tattersall, I. \& Sussman, R. W. (Eds). New York: Plenum Press.

Preuschoft, H. (1985). On the quality and magnitude of mechanical stresses in the locomotor system during rapid movements. Z. Morphol. Anthropol. 75: 245-262.

Preuschoft, H. (1990). Gravity in primates and its relation to body shape and locomotion. Hum. Evol. 5: 559-578.

Rafferty, K. L. \& Ruff, C. B. (1994). Articular structure and function in Hylobates, Colobus, and Papio. Am. J. Phys. Anthropol. 94: 395-408.

Reason, R. C. (1978). Support use behavior in Mindanao tarsiers (Tarsius syrichta carbonarius). J. Mammal. 59: 205-206.

Richard, A. F. (1992). Aggressive competition between males, female-controlled polygyny and sexual monomorphism in a Malagasy primate, Propithecus verreauxi. J. Hum. Evol. 22: $395-406$

Roberts, M. \& Cunningham, B. (1986). Space and substrate use in captive western tarsiers, Tarsius bancanus. Int. J. Primatol. 7: $113-130$.

Rohlf, F. J. \& Slice, D. E. (1995). BIOMstat for Windows. Setauket, NY: Exeter Software.

Rose, K. D. \& Walker, A. (1985). The skeleton of early Eocene Cantius, oldest lemuriform primate. Am. J. Phys. Anthropol. 66: $73-89$.

Ruff, C. B. (1987). Structural allometry of the femur and tibia in Hominoidea and Macaca. Folia Primatol. 48: 9-49.

Ruff, C. B. (1988). Hindlimb articular surface allometry in Hominoidea and Macaca, with comparisons to diaphyseal scaling. J. Hum. Evol. 17: 687-714.

Ruff, C. B. (1989). New approaches to structural evolution of limb bones in primates. Folia Primatol. 53: 142-159.

Ruff, C. B. \& Hayes, W. C. (1983). Cross-sectional geometry of Pecos Pueblo femora and tibiae - a biomechanical investigation: I. method and general patterns of variation. Am. J. Phys. Anthropol. 60: 359-381.

Ruff, C. B. \& Runestad, J. A. (1992). Primate limb bone structural adaptations. Annu. Rev. Anthropol. 21: 407-433.

Runestad, J. A. (1994). Humeral and femoral diaphyseal crosssectional geometry and articular dimensions in Prosimii and platyrrhini (primates) with application for reconstruction of body mass and locomotor behavior in Adapidae (Primates: Eocene). $\mathrm{PhD}$ thesis, Johns Hopkins University.

Runestad, J. A. (1997). Postcranial adaptations for climbing in Loridae (Primates). J. Zool. (Lond.) 242: 261-290.

Runestad, J. A., Ruff, C. B., Nieh, J. C., Thorington, R. W., Jr. \& Teaford, M. F. (1993). Radiographic estimation of long bone cross-sectional geometric properties. Am. J. Phys. Anthropol. 90: $207-213$.

Schaffler, M. B., Burr, D. B., Jungers, W. L. \& Ruff, C. B. (1985). 
Structural and mechanical indicators of limb specialization in primates. Folia Primatol. 45: 61-75.

Simons, E. L. \& Rumpler, Y. (1988). Eulemur: new generic name for species of Lemur other than Lemur catta. C. R. Acad. Sci. Paris 307: 547-551.

Smith, R. J. (1994). Degrees of freedom in interspecific allometry: an adjustment for the effects of phylogenetic constraint. Am. $J$ Phys. Anthropol. 93: 95-107.

Stephan, H. \& Bauchot, R. (1965). Hirn-Körpergewichtsbeziehungen bei den halbaffen (Prosimii). Acta Zool. 46: 209-231.

Subramoniam, S. (1957). Some observations on the habits of the slender loris Loris tardigradus (Linnaeus). J Bombay Nat. Hist. Soc. 54: 386-398.

Szalay, F. S. \& Dagosto, M. (1980). Locomotor adaptations as reflected on the humerus of Paleogene primates. Folia Primatol. 34:1-45.

Tattersall, I. \& Schwartz, J.H. (1991). Phylogeny and nomenclature in the 'Lemur-group' of Malagasy strepsirhine primates. Anthropol. Pap. Am. Mus. Nat. Hist. 69: 3-18.

Terranova, C. (1995a). Leaping behaviors and the functional morphology of strepsirhine primate long bones. Folia Primatol. 65: $181-201$.

Terranova, C. (1995b). Functional morphology of leaping behaviors in galagids: associations between landing limb use and diaphyseal geometry. In Creatures of the dark: the nocturnal prosimians: 473-494. Alterman, L., Doyle, G. A. \& Izard, M. K. (Eds). New York: Plenum Press.

Thalmann, U., Haubold, H. \& Martin, R. D. (1989). Pronycticebus neglectus - an almost complete adapid primate specimen from the Geiseltal (GDR). Palaeovertebrata 19: 115-130.

Tilden, C. D. (1990). A study of locomotor behavior in a captive colony of red-bellied lemurs (Eulemur rubriventer). Am. J. Primatol. 22: 87-100.

Tsutakawa, R. K. \& Hewett, J. E. (1977). Quick test for comparing two populations with bivariate data. Biometrics 33: 215-219.
Vasey, N. (1992). Positional behavior of the white sifaka (Propithecus verreauxi) at Beza Mahafaly Reserve, southwestern Madagascar. Abstracts of the Fourteenth Congress of the International Primatological Society, Strasbourg: 0111.

Vincent, F. (1969). Contribution à l'étude des prosimiens africains: le Galago de Demidoff. Reproduction (biologie, anatomie, physiologie) et comportement. Thèse d'État, Paris, CNRS A.O. 3575, I and II.

Walker, A. (1970). Post-cranial remains of the Miocene Lorisidae of East Africa. Am. J. Phys. Anthropol. 33: 249-262.

Walker, A. C. (1974). Locomotor adaptations in past and present prosimian primates. In Primate locomotion: 349-381. Jenkins, F. A., Jr. (Ed.). New York: Academic Press.

Walker, A. C. (1979). Prosimian locomotor behavior. In The study of prosimian behavior: 543-565. Doyle, G. A. \& Martin, R. D. (Eds). New York: Academic Press.

Walker, S. E. (1994). Positional behavior and habitat use in Chiropotes satanas and Pithecia pithecia. XIV Congress of the Intl. Primatol. Soc., Strasbourg: Université Louis Pasteur: 195-201.

Walker, S. E. (1996). The evolution of positional behavior in the saki-uakaris (Pithecia, Chiropotes, and Cacajao). Adaptive radiations of neotropical primates: 335-367. In Norconk, M., Rosenberger, A. \& Garber, P. (Eds). New York: Plenum Press.

Warren, R. D. \& Crompton, R. H. (1997). Locomotor ecology of Lepilemur edwardsi and Avahi occidentalis. Am. J. Phys. Anthropol. 104: 471-486.

Wilkinson, L. (1992). SYSTAT: the System for Statistics. Evanston, IL: SYSTAT, Inc.

Yoder, A. D. (1997). Back to the future: a synthesis of strepsirrhine systematics. Evol. Anthropol. 6: 11-22.

Yoder, A. D., Cartmill, M., Ruvolo, M., Smith, K. \& Vilgalys, R. (1996). Ancient single origin for Malagasy primates. Proc. Natl Acad. Sci. USA 93: 5122-5126. 